\title{
ИГЛОУКАЛЫВАНИЕ В ПРОФИЛАКТИКЕ, ЛЕЧЕНИИ ТРАВМ И УЛУЧШЕНИИ УСПЕВАЕМОСТИ У СПОРТСМЕНОВ: ОБЗОР ЛИТЕРАТУРЫ
}

\section{ОБЗОР СТАТЬИ}

JUNIOR, Julio Cesar Dias ${ }^{1}$

Junior, Julio Cesar Dias. Иглоукалывание в профилактике, лечении травм и улучшение производительности у спортсменов: Обзор литературы. Revista Científica Multidisciplinar Núcleo do Conhecimento. 04 год, Эд. 10, Vol. 10, стр. 5998. Октябрь 2019 года. ISSN: 2448-0959, ссылка для доступа: https://www.nucleodoconhecimento.com.br/здравоохранение/иглоукалыв ание-в-профилактике

1 Степень в области физиотерапии в Университетском центре Арараквара UNIARA - 2005 (Araraquara-SP); Лато Сэнсу последипломной терапии в области ортопедической и травматологической фризиотерапии из Института Коэна Ортопедия, реабилитация и спортивная медицина - 2006 (Сан-ПаулуSP)Обучение остеопатической ручной терапии Институтом Цефисы - 2008 (Araraquara-SP); Профрессиональное совершенствование в области глобального постулального перевоспитания и сенсорного моторного перепрограммирования - RPG/RSM Институтом системных исследований Паулиста - IPES - 2010 (Рибейрао Прето-СП); Лато Сэнсу аспирантуру по системной иглоукалывании из Института системных исследований Паулиста - IPES - 2013 (Рибейран ПретоСП); Stricto sensu Postgraduate Степень магистра территориального развития и окружающей среды от Университетского центра Araraquara - UNIARA - 2016 (Araraquara - SP); Профеессиональное совершенствование клинического и функционального пилатеса Институтом системных исследований Паулиста IPES - 2016 (Рибейран Прето-СП). 


\section{PE3ЮME}

Исследования показали, что иглоукалывание улучшает фризическую работоспособность у профессиональных спортсменов, но большой проблемой является спортивные травмы, которые могут оставить их вдали от деятельности В течение длительного времени. В ходе исследования был проведен обзор литературы, в ходе которой была изыскивать эфффективность метода в профилактике, повышении производительности и лечении поражений. Некоторые авторы иллюстрируют и разъясняют процесс нейрофизиологии боли и то, как иглоукалывание может вмешиваться в эту проблему, другие, разработать и применять протоколы для достижения улучшения производительности, лечения заболеваний и профилактики Травмы. Среди результатов были найдены восемьдесят девять статей на эту тему, где: двадцать два сообщили лечения поражений и тридцать семь профилактики и улучшения спортивных результатов, направляя применение один раз в неделю, 20 - 30 минут, представляя удовлетворительные результаты для проанализированных данных. Основываясь на этой литературе и научнообоснованной практике можно сделать вывод, что иглоукалывание является большим вмешательством для достижения этих целей в области спорта.

Ключевые слова: иглоукалывание, травмы, боль, производительность.

\section{ВВЕДЕНИЕ}

На протяжении нескольких тысячелетий иглоукалывание используется как форма профиллактики и лечения различных заболеваний организма. Этот метод китайской медицины манипулировали иглы камней и рыбы прыщи на протяжении каменного века (3000 лет до н.э.).1, 2 Классический желтый император: Хуан Ди Ней Цзин, является одним из старейших записей традиционной китайской медицины (MTC), интегрируя по сей день фрилософрские основы, которые концептуализируют баланс Вселенной и природы, которая в ее (китайском) видении, энергия называется Чи или Ци. Этот фрактор имеет два

Disponível em: https://www.nucleodoconhecimento.com.br/здравоохранение/иглоукалывание-в- 
антагонистических принципов, которые завершены и, как правило, находятся в равновесии, даже если он находится под влиянием Вселенной, называется Инь и Ян. ${ }^{3}$

Иглоукалывание определяется как гармонизация человека с окружающей средой, в которой он, не только, вставки иглы и устранения проблемы болезни, но достижение идеала профилактики различных патологий.4, 5 Это процедура, выполняемая с терапевтическая цель, не является токсичной, без использования химических элементов, с минимальными побочными эффректами, хотя он способен выпустить эндогенные вещества, такие как нейротрансмиттеры. 4, 6, 7, 8, 9

Вмешательство заключается в стимулировании acupoints для достижения желаемого терапевтического эффректа и достижения гомеостаза организма. Многие исследования иллюстрируют эффекты неопиоидной теории нейронной (ингибирует нервные импульсы, действующие на периферическая и центральную нервную систему); гуморальная теория (стимулирует высвобождение эндогенных опиоидов, других гормонов и нейротрансмиттеров).10, 11 Цель в борьбе с болью, связь игл с электрическим током, называется электроакупунктура, потенциаты и представляет преимущества в клиническая практика, в дополнение к используется также как: аурическая иглоукалывание; черепная пунция; моксабустао; присоски; лазерная иглоукалывание. 3, 10

В спорте, использование технологий в поисках лучших результатов продолжает расти, превышая пределы человеческого тела. Несколько естественных или интегративных методов лечения изучаются в качестве источника дополнительной терапии для улучшения спортивных условий. Хотя количество исследований является скудным, принятие иглоукалывание по-прежнему очень любопытно, так как многие люди по-прежнему сомневаются в научных данных. 9 Однако, его использование в спортивной среде растет, действуя в лечении боли и спортивных травм, ускоряя процесс восстановления человека. Еще одним вопросом является эфффективное вмешательство в улучшение фризической 
работоспособности и предотвращение травм от спортсменов-любителей и профессиональных спортсменов.13, 14

\section{ЦЕЛЬ}

Целью этой работы было проведение библиографического обследования использования иглоукалываниев в профилактике, улучшении спортивных результатов и лечении травм в различных спортивных условиях.

\section{МЕТОДОЛОГИЯ}

Для получения информации о: иглоукалывание в профилактике, повышении производительности и лечении спортивных травм было проведено библиографическое исследование в базах данных Scielo, Google Academico и Scoopus. Были использованы следующие ключевые слова: иглоукалывание; иглоукалывание и боль; иглоукалывание в профилактике; спортивная травма и иглоукалывание; иглоукалывание и улучшение спортивных результатов; лечения травм и иглоукалывание.

Для того чтобы delimit вырез этого изучения, первоначально скрининг был унесен среди многочисленнGр найденных статьей, totaling 89 рукописей, выбирая 22 которые адресовали вопрос иглоукалывания в обработке ушибов и 37 адресуя предохранение ушиба спортов и улучшение спортивных результатов. Основываясь на этом анализе, стоит отметить, что из всех исследований, найденных в первую очередь, вселенная исследований состояла из 59 статей, опубликованных в научных журналах, конгресспом, книгах, веб-сайтах, которые в названии, абстрактные или ключевые слова терминологии, используемые в ходе исследования.

\section{РЕЗУЛЬТАТЫ И ОБСУЖДЕНИЕ}

В этом поиске приводится несколько статей (Графр 1; Таблица 1), будучи выполнена в изоляции через ключевые слова.

Disponível em: https://www.nucleodoconhecimento.com.br/здравоохранение/иглоукалывание-впрофилактике 
График 1: Общее количество статей, найденных и используемых в поиске.

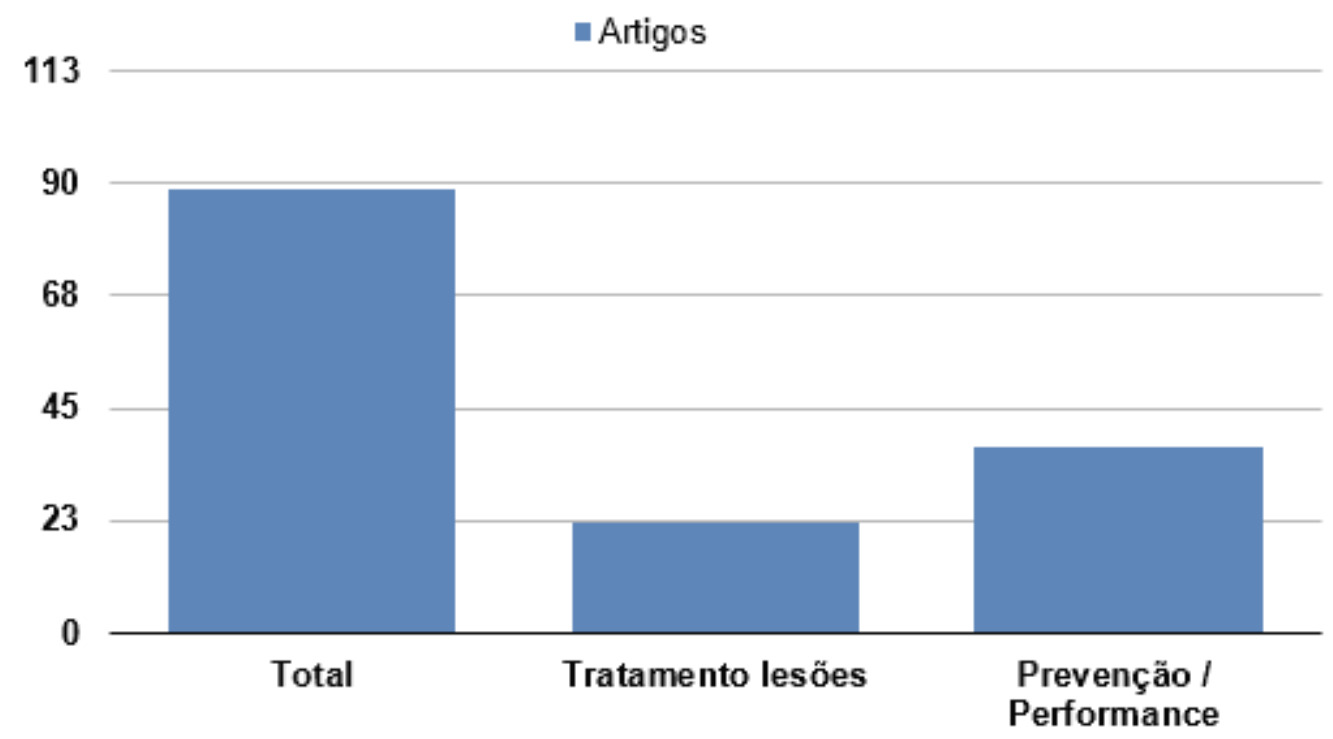

Таблица 1: Статьи, связанные с профрилактикой, улучшением спортивных результатов и лечением спортивных травм.

\begin{tabular}{|c|c|c|}
\hline Авторы & Название статьи & Журналы/Анаис/Конгрессы/Сайты \\
\hline $\begin{array}{l}\text { Ehrlich D, Haber } \\
\text { P, } 1992\end{array}$ & $\begin{array}{l}\text { Influence of } \\
\text { acupuncture on pysical } \\
\text { performance capacity } \\
\text { and Haemodynamic } \\
\text { Parameters }\end{array}$ & J. Sports Med \\
\hline $\begin{array}{lr}\text { Santos } & \text { VC, } \\
\text { Kawano } & \text { MM, } \\
\text { Banja RA, } 2008\end{array}$ & $\begin{array}{l}\text { Acupuntura na melhora } \\
\text { da performance em } \\
\text { atletas juvenis de } \\
\text { handebol }\end{array}$ & Rev Saúde e Pesq \\
\hline $\begin{array}{l}\text { Rubio K, Godoy } \\
\text { Moreira F, } 2008\end{array}$ & $\begin{array}{l}\text { A dor em corredores } \\
\text { com fascite plantar: o } \\
\text { uso da acupuntura }\end{array}$ & Rev Dor \\
\hline
\end{tabular}




\begin{tabular}{|c|c|c|}
\hline $\begin{array}{ll}\text { Pires } & \text { TF, } \\
\text { Pellegrinotti } & \text { IL, } \\
2010 & \end{array}$ & $\begin{array}{l}\text { Acupuntura na } \\
\text { Performance Atlética: } \\
\text { Estudo Exploratório }\end{array}$ & 8aㅗ Mostra Acadêmica da UNIMEP \\
\hline $\begin{array}{l}\text { Yang HY, Liu TY, } \\
\text { Gao M, } 2006\end{array}$ & $\begin{array}{l}\text { Electrical acupoint } \\
\text { stimulation increases } \\
\text { athletes rapid strength }\end{array}$ & Zhongguo Zhen Jiu \\
\hline $\begin{array}{ll}\text { Luna } & \text { MP, } \\
\text { Fernandes } & \text { Filho } \\
\text { J, } 2005 & \end{array}$ & $\begin{array}{l}\text { Efeitos da Acupuntura } \\
\text { na performance de } \\
\text { Atletas velocista de alto } \\
\text { rendimento do Rio de } \\
\text { Janeiro }\end{array}$ & Fit e Perform J \\
\hline $\begin{array}{l}\text { Dias Junior JC, } \\
\text { Marino DM, } 2019\end{array}$ & $\begin{array}{l}\text { Acupuntura na } \\
\text { prevenção de lesões } \\
\text { musculares em atletas } \\
\text { de futebol profissional }\end{array}$ & Rev Fisiot S Fun \\
\hline Maciocia G, 2007 & $\begin{array}{l}\text { Os fundamentos da } \\
\text { medicina chinesa: um } \\
\text { texto abrangente para } \\
\text { acupunturistas } \\
\text { fitoterapeutas }\end{array}$ & Книга \\
\hline $\begin{array}{ll}\text { Akimoto } & \text { T, } \\
\text { Nakahori } & \text { C, } \\
\text { Aizawa } & \text { K, } \\
\text { Kimura } & \text { F, } \\
\text { Fukubayashi } & \text { T, } \\
\text { Kono I, 2003 } & \end{array}$ & $\begin{array}{l}\text { Acupuncture and } \\
\text { responses of imunoligic } \\
\text { and endocrine markers } \\
\text { during competition }\end{array}$ & Med Sci in Sports Exerc \\
\hline $\begin{array}{ll}\text { Karvelas } & \text { BR, } \\
\text { Hoffman } & \text { MD, } \\
\text { Zeni Al, } 1996\end{array}$ & $\begin{array}{l}\text { Acute Effects of } \\
\text { Acupuncture } \\
\text { Physiological on } \\
\text { Psychological and }\end{array}$ & Arch Phys Med Rehabil \\
\hline
\end{tabular}




\begin{tabular}{|c|c|c|}
\hline & $\begin{array}{l}\text { Responses to Cycle } \\
\text { Ergometry }\end{array}$ & \\
\hline $\begin{array}{l}\text { Fry AC, Kraemer } \\
\text { KJ, } 1997\end{array}$ & $\begin{array}{l}\text { Resistance exercise ov } \\
\text { ertraing } \\
\text { and overreaching: neur } \\
\text { oendocrine responses }\end{array}$ & Sports Med \\
\hline KnardahI S, 1998 & $\begin{array}{l}\text { Sympathetic } \\
\text { nerve activity after } \\
\text { acupuncture in humans }\end{array}$ & $\begin{array}{l}\text { Department of Clinical } \\
\text { Neurophysiology }\end{array}$ \\
\hline $\begin{array}{l}\text { Barlas PJ, } \\
\text { Robinson JA, Ba } \\
\text { xter GD, } 2000\end{array}$ & $\begin{array}{l}\text { Lack ofeffect of acupun } \\
\text { cture upon signs } \\
\text { and symptoms of delay } \\
\text { ed } \\
\text { onset muscle soreness }\end{array}$ & Clinical Physio \\
\hline $\begin{array}{l}\text { Rossetto SC, } \\
2009\end{array}$ & $\begin{array}{l}\text { Acupuntura nos } \\
\text { Esportes }\end{array}$ & Книга \\
\hline $\begin{array}{l}\text { França D, } \\
\text { Fernandes- } \\
\text { Senna V, Cortez } \\
\text { CM, } 2004\end{array}$ & 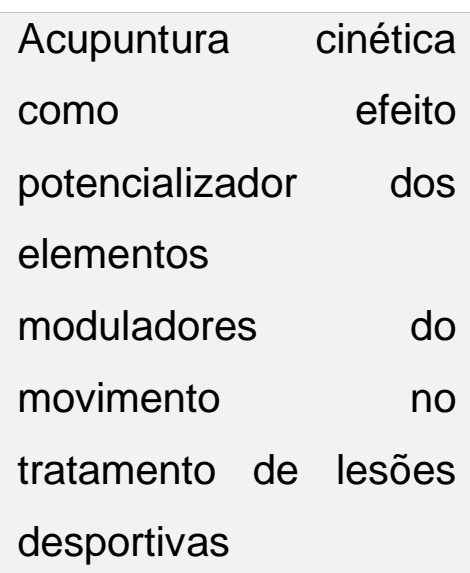 & Fisioter Bras \\
\hline $\begin{array}{l}\text { Wadsworth L T, } \\
2006\end{array}$ & $\begin{array}{l}\text { Acupuncture in sports } \\
\text { medicine }\end{array}$ & Curr Sports Med Rep \\
\hline Barela J A, 2000 & $\begin{array}{l}\text { Estratégias de Controle } \\
\text { em Movimentos } \\
\text { Complexos: Ciclo } \\
\text { Percepção - Ação no } \\
\text { Controle Postural }\end{array}$ & Rev Paul de Educ Fís \\
\hline
\end{tabular}




\begin{tabular}{|c|c|c|}
\hline $\begin{array}{l}\text { Papler PG et al., } \\
1999\end{array}$ & $\begin{array}{l}\text { Reabilitação do joelho. } \\
\text { In: Greve J.M. A. e } \\
\text { Amattuzzi, } \\
\text { Medicina de } \\
\text { reabilitação aplicada à } \\
\text { ortopedia } \\
\text { traumatologia }\end{array}$ & Книга \\
\hline $\begin{array}{l}\text { Gemeo LH. } \\
\text { Ignatti C, } 2004\end{array}$ & $\begin{array}{l}\text { Acupuntura como } \\
\text { Ferramenta Auxiliar do } \\
\text { Aumento da } \\
\text { Performance } \\
\text { Desportiva. In: Anais do } \\
\text { Simpósio Internacional } \\
\text { de Ciências Integradas } \\
\text { da UNAERP }\end{array}$ & Anais Simpósio \\
\hline Frasca L, 2011 & $\begin{array}{l}\text { Desempenho na Ponta } \\
\text { da Agulha }\end{array}$ & Rev Farmac \\
\hline Costa V, 2013 & $\begin{array}{l}\text { Acupuntura Previne } \\
\text { Lesões e ajuda a } \\
\text { melhorar } \\
\text { Desempenho nas } \\
\text { Pistas [periódico na } \\
\text { internet] }\end{array}$ & $\begin{array}{l}\text { http://blogs.oglobo.globo.com/pulso/ } \\
\text { post/acupuntura-previne-lesoes- } \\
\text { ajuda-melhorar-desempenho-nas- } \\
\text { pistas-500798.html. }\end{array}$ \\
\hline Luna M, 2016 & $\begin{array}{l}\text { Os Benefícios da } \\
\text { Acupuntura no Esporte }\end{array}$ & $\begin{array}{l}\text { http://www.ibramrp.com.br/noticia/49 } \\
\text { /os-beneficios-da-acupuntura-no- } \\
\text { esporte }\end{array}$ \\
\hline $\begin{array}{l}\text { Bopp-Limoge C, } \\
1998\end{array}$ & $\begin{array}{l}\text { L`acupuncture Permet- } \\
\text { elle D`ameliorer les } \\
\text { Performances } \\
\text { Sportives Stude } \\
\text { Personnelle a Propos }\end{array}$ & These Medicine \\
\hline
\end{tabular}

Disponível em: https://www.nucleodoconhecimento.com.br/здравоохранение/иглоукалывание-в- 


\begin{tabular}{|c|c|c|}
\hline & $\begin{array}{l}\text { de } 35 \text { Sportifs de haut } \\
\text { niveau. }\end{array}$ & \\
\hline Lin ZP et al., 2009 & $\begin{array}{l}\text { Effects of acupuncture } \\
\text { stimulation on recovery } \\
\text { ability for male elite } \\
\text { basketball athletes }\end{array}$ & Amer Jour of Chin Med \\
\hline $\begin{array}{l}\text { Lin, ZP et al., } \\
2009\end{array}$ & $\begin{array}{l}\text { Effect of auricular } \\
\text { acupuncture on oxygen } \\
\text { consumption of boxing } \\
\text { athletes }\end{array}$ & Chin Med Jour \\
\hline $\begin{array}{l}\text { Dhillon S et al., } \\
2008\end{array}$ & $\begin{array}{l}\text { The acute effect of } \\
\text { acupuncture on } 20-\mathrm{km} \\
\text { cycling performance. }\end{array}$ & Clin Jour of Spo Med \\
\hline $\begin{array}{l}\text { Hubscher M et } \\
\text { al., } 2010\end{array}$ & $\begin{array}{l}\text { Immediate effects of } \\
\text { acupuncture on } \\
\text { strength performance: a } \\
\text { ramdomized, controlled } \\
\text { crossover trial }\end{array}$ & Euro Jour of Appli Physi \\
\hline $\begin{array}{l}\text { Geng } L J \text { et al., } \\
1995\end{array}$ & $\begin{array}{l}\text { Investigation on the } \\
\text { effects of ear } \\
\text { acupressure on } \\
\text { exercise-induced lactic } \\
\text { acid levels and the } \\
\text { implications for athletic } \\
\text { training }\end{array}$ & Amer Jour of Acupu \\
\hline Franco RS, 2012 & $\begin{array}{l}\text { Avaliação do Efeito da } \\
\text { Acupuntura sobre o } \\
\text { Desempenho Físico } \\
\text { pelo Teste do Banco de } \\
\text { Harvard }\end{array}$ & Dissertação \\
\hline
\end{tabular}




\begin{tabular}{|c|c|c|}
\hline $\begin{array}{l}\text { Fonseca LP, } \\
\text { Lessa JFM, } 2011\end{array}$ & $\begin{array}{l}\text { Efeito da Aplicação da } \\
\text { Acupuntura na } \\
\text { Resistência Muscular } \\
\text { Localizada de Membros } \\
\text { Superiores em } \\
\text { Praticantes de } \\
\text { Exercício Resistido. }\end{array}$ & Mobografia \\
\hline $\begin{array}{lr}\text { Belmiro } & \text { H, } \\
\text { Vicentini } & \text { D, } \\
\text { Camilotti } & \text { CM, } \\
2013 & \end{array}$ & $\begin{array}{l}\text { Efeitos da Acupuntura } \\
\text { no Desempenho Motor } \\
\text { de Atletas. }\end{array}$ & Rev Fac Educ Fis \\
\hline $\begin{array}{l}\text { Rubio K; Godoy } \\
\text { Moreira F, } 2007\end{array}$ & $\begin{array}{l}\text { A representação da dor } \\
\text { em atletas olímpicos } \\
\text { brasileiros }\end{array}$ & Rev Dor \\
\hline Parisotto D, 2014 & $\begin{array}{l}\text { Efeito Imediato da } \\
\text { Aplicação da } \\
\text { Acupuntura na Dor } \\
\text { Muscular Tardia e na } \\
\text { Capacidade de } \\
\text { Contração Muscular }\end{array}$ & Dissertação \\
\hline Staud R, 2007 & $\begin{array}{l}\text { Mechanisms of } \\
\text { acupunture analgesia: } \\
\text { effective therapy for } \\
\text { musculoskeletal pain? }\end{array}$ & Curr rheumatol Rep \\
\hline $\begin{array}{l}\text { Bucinskaite } \quad \text {, } \\
\text { Lundeberg T, } \\
\text { Stenfors C, } \\
\text { Ekblom A, Dahlin } \\
\text { L, Theodorsson } \\
\text { E, } 1994\end{array}$ & $\begin{array}{l}\text { Effects of electro- } \\
\text { acupuncture and } \\
\text { pysical exercice on } \\
\text { regional concentrations } \\
\text { of neuropeptides in rat } \\
\text { brain }\end{array}$ & Brain research \\
\hline
\end{tabular}




\begin{tabular}{|c|c|c|}
\hline Shang C, 2009 & $\begin{array}{l}\text { Prospective tests on } \\
\text { biological models of } \\
\text { acupuncture }\end{array}$ & $\begin{array}{l}\text { Evid Based Complement Alternat } \\
\text { Med. }\end{array}$ \\
\hline Bowsher D,1988 & $\begin{array}{l}\text { Mechanisms of } \\
\text { acupuncture. In: Filshie } \\
\text { J, White A. editors. } \\
\text { Medial Acupuncture: a } \\
\text { western scientific } \\
\text { approach. }\end{array}$ & Книга \\
\hline Ma SX, 2004 & $\begin{array}{l}\text { Neurobiology of } \\
\text { acupuncture: Toward } \\
\text { CAM }\end{array}$ & $\begin{array}{l}\text { Evid Based Complement Alternat } \\
\text { Med }\end{array}$ \\
\hline $\begin{array}{l}\text { Li J, Wang Q, } \\
\text { Liang H, Dong H, } \\
\text { Li Y, Ng EH, et al., } \\
2012\end{array}$ & $\begin{array}{l}\text { Biophysical } \\
\text { characteristics of } \\
\text { meridians and } \\
\text { acupoints: a systematic } \\
\text { review. }\end{array}$ & $\begin{array}{l}\text { Evid Based Complement Alternat } \\
\text { Med. }\end{array}$ \\
\hline $\begin{array}{l}\text { Lee, SH, Chung, } \\
\text { SH, Lee, JS, Kim, } \\
\text { SS, Shin, HD, } \\
\text { Lim, BV, et al., } \\
2002\end{array}$ & $\begin{array}{l}\text { Effects Acupunturaq on } \\
\text { the } \\
\text { hydroxytryptamine } \\
\text { synthesis and } \\
\text { tryptophan hydroxylase } \\
\text { expression in dorsal in } \\
\text { the dorsal raphe of } \\
\text { exercice rats. }\end{array}$ & Neurocienses Letters \\
\hline $\begin{array}{l}\text { Zyloney CE, } \\
\text { Jensen K, Polich } \\
\text { G, Loiotile RE, } \\
\text { Cheetham A, } \\
\text { LaViolette PS, et } \\
\text { al., } 2010\end{array}$ & $\begin{array}{l}\text { Imaging the functional } \\
\text { connectivity of the } \\
\text { Periaqueductal Gray } \\
\text { during genuine and } \\
\text { sham }\end{array}$ & Mol pain \\
\hline
\end{tabular}




\begin{tabular}{|c|c|c|}
\hline & $\begin{array}{l}\text { electroacupuncture } \\
\text { treatment. }\end{array}$ & \\
\hline $\begin{array}{l}\text { Minori AET, Mejia } \\
\text { DPM, } 2007\end{array}$ & $\begin{array}{l}\text { Atuação da Acupuntura } \\
\text { para o Tratamento de } \\
\text { LER/DORT no Ombro. }\end{array}$ & Monografia \\
\hline $\begin{array}{l}\text { Brum } \quad \mathrm{KN}, \\
\text { Alonso, } \\
\text { Brech } \text { GC, } 2009\end{array}$ & $\begin{array}{l}\text { Tratamento de } \\
\text { massagem em } \\
\text { acupuntura em } \\
\text { corredoresrecreacionai } \\
\text { s com síndrome do } \\
\text { piriforme }\end{array}$ & Arq Cienc Sau \\
\hline Hongwen S, 2003 & $\begin{array}{l}\text { Clinical Observation on } \\
\text { Acupuncture Treatment } \\
\text { of Piriformis Syndrome. }\end{array}$ & J Tradit Chin Med. \\
\hline $\begin{array}{l}\text { Rocha } \\
\text { Vilela Junior } \\
\text { GB, } \\
\text { Martins } \\
\text { Manzatto } \\
\text { Grande }\end{array}$ & $\begin{array}{l}\text { Análise Comparativa } \\
\text { Eletromiográfica do } \\
\text { Reto Femoral em } \\
\text { Isometria na Posição } \\
\text { Inferior } \\
\text { Agachamento Wall } \\
\text { Slide, antes e após a } \\
\text { Aplicação } \\
\text { Acupuntura no Ponto } \\
\text { ST45 }\end{array}$ & Rev Bras Cien e Mov \\
\hline $\begin{array}{l}\text { Pinheiro RG, } \\
\text { Mejia DPM, } 2012\end{array}$ & $\begin{array}{l}\text { Efeito da Acupuntura na } \\
\text { Melhora do Paciente } \\
\text { com Quadro Álgico de } \\
\text { Lesão de Menisco } \\
\text { Medial. }\end{array}$ & Monografia \\
\hline $\begin{array}{l}\text { Nunes EA, Mejia } \\
\text { DPM, } 2012\end{array}$ & $\begin{array}{lr}\text { Tratamento } & \text { de } \\
\text { Acupuntura } & \text { para }\end{array}$ & Monografia \\
\hline
\end{tabular}




\begin{tabular}{|c|c|c|}
\hline & $\begin{array}{l}\text { Combater Dores nos } \\
\text { Ombros. }\end{array}$ & \\
\hline Tolentino F, 2016 & $\begin{array}{l}\text { Efeito de um } \\
\text { Tratamento com } \\
\text { Auriculoterapia na Dor, } \\
\text { Funcionalidade } \\
\text { Mobilidade de Adultos } \\
\text { com Dor Lombar } \\
\text { Crônica. }\end{array}$ & Dissertação \\
\hline
\end{tabular}

\section{АКУПЕКУРУС В ПРЕВЕНЦИЯ ВИНСУКТО}

Профрилактика травм в спорте - это большая битва, которую предстоит выиграть профессионалам, которые работают со спортсменами. В фрутболе мышечная травма соответствует 20-40\% всех спортивных травм, преимущественно 80-90\% в нижних конечностях. ${ }^{15}$

Мышечная травма является большим злодеем всех спортсменов, из различных видов спорта, и может оставить их от их деятельности в течение длительного периода. Таким образом, интересно представить предложение по профилактическому вмешательству, в результате чего идея техники для предотвращения или снижения рисков этого вида травм у спортсменов. В этом случае иглоукалывание оказывается полезным методом.

В его исследовании, Диас Младший 16, приняли участие 54 спортсменов-мужчин, принадлежащих к профессиональной фрутбольной команды. Они были распределены на 6 групп: группа 1 - иглоукалывание для ребалансировки системы, найденная путем оценки; группа 2 - которая получила протокол с конкретными точками: селезенка поджелудочная железа 3, селезенка поджелудочная железа 6 (рисунок 1А) и желудок 36 (рисунок 1В); группа 3 желудок 36 (рисунок 1В); группа 4 - поджелудочная железа селезенки 6 (рисунок 1A); группа 5 - иглоукалывание уха; контрольная группа - не получила никакого 
вмешательства. После восьми сеансов, по одному в неделю, результаты показали: группы 1 и 2 не представляли какого-либо вида травм; группа 4: два поражения; группы 3 и 5: представлено 1 поражения; контроль: представлено 6 случаев мышечных проблем.

Рисунок 1 А: селезенка поджелудочная железа 3 - на медиальной стороне стопы, посттеро-нижней части плюсневого фалина сустава, в линии соединения темной и светлой кожи; селезенка поджелудочной железы 6: 3 tsun над медиальным малеолом, на постеромедиальном краю голени; В: живот 36 - 3 tsun ниже коленной чашечки между передней мышцы голени и длинной мышцы прогиба пальцев; желудок 37 - 3 цун ниже Зусанли (Е36), на боковой передней стороне мышцы голени; желудок 38 - 8 tsun ниже колена, 2 tsun ниже точки Shangjuxu (E37), на стороне передней мышцы голени; живот 41 - в серпотной середине лодыжки выше крестообразной связки, между сухожилиями длинной халле разгибателя мышцы и длинный разгибатель пальцев.

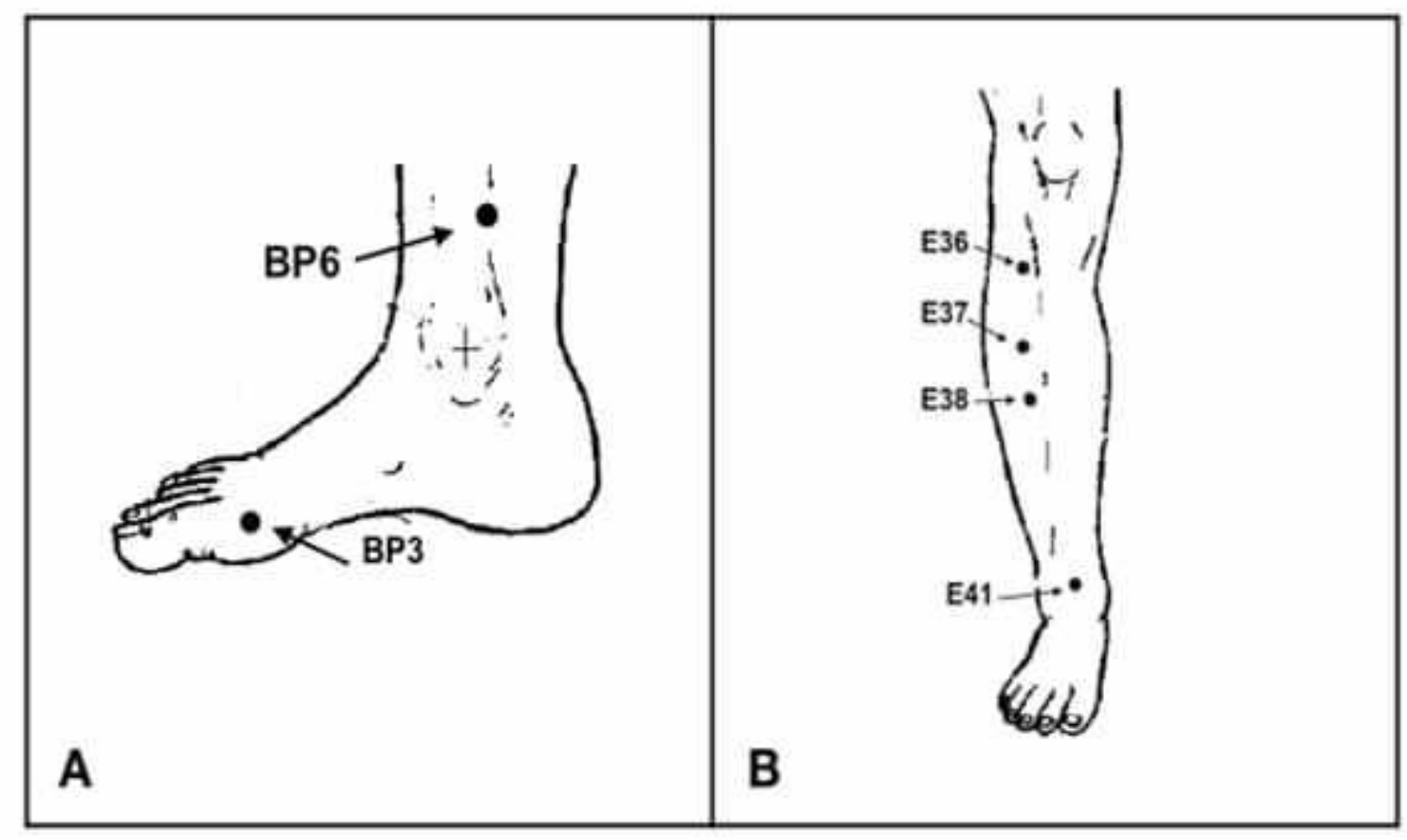

Источник: Вэнь ${ }^{17}$

Disponível em: https://www.nucleodoconhecimento.com.br/здравоохранение/иглоукалывание-в- 
Селезенка поджелудочной железы имеет функцию извлечения энергии из пищи, распределения в организме и контроля крови в кровеносных сосудах. Сильное представление Ци будет транспортироваться во все мышцы тела, особенно в конечности, но если Ци в дефиците, энергия не будет передаваться в мышечную ткань и спортсмен будет представлять усталость и ослабленные мышцы. ${ }^{18}$

По данным Рос ${ }^{c}$ 19, селезенки точек поджелудочной железы 3 и 6 связаны с желудком 36 путем тонинат крови Ци. Земной элемент отвечает за энергетический баланс и наличие Ци и крови в качестве источников энергии для умственной, эмоциональной и фризической активности. МТС, сообщает, что, тонируя этот элемент, он поддерживает мышцы, питаемые Ци и Сюэ (кровь в ЦМТ), направленных на улучшение спортивных результатов. Это поддерживает обязательство тон органа, который производит Xue (Liver) и поддерживает энергетическую жидкость (Spleen поджелудочной железы и почек), так как функциональность крови, чтобы питать тело, в дополнение к завершению питательного действия Ци.

Мышечные тренировки, релаксация и сократительная сила связана с питанием печени Хue. Если питание недостаточно, судороги и парестезии конечностей приведет к травмам. С другой стороны селезенка контролирует хие внутри сосудов и удаляет ци от передачи продуктов в организм: Сильный Ци, будет передавать хорошую энергию мышц; ослабленный Ци приведет к усталости и слабой мышцы. ${ }^{19,} 20$

На основе этого доказательства эта техника практикуется в спорте, представляя быстрые результаты, улучшая качество мышечной силы, кардиореспираторные условия, гибкость и психическое и физическое благополучие спортсменов. ${ }^{20,} 21$, 22 Ян и 22 сотрудников, достигли значительного увеличения мышечной силы, обеспечивая улучшение скорости спортсменов. В свою очередь, Луна и сотрудник $^{n} 24$, заявил, что стимуляция точек иглоукалывания улучшает спортивные показатели, мышечная пластичность предотвращения травм. 
Исследование, проведенное в Японии подчеркивает влияние иглоукалывание на физическое благополучие женщин-фрутболисток во время соревнований. Они были разделены на две группы, где одна была представлена на лечение, а другая контроля. Уровни кортизола (оценка эндокринной системы) и оценка фризического благополучия оценивались с помощью вопросника POMS (оценивает физическое и психическое состояние): наблюдалось улучшение иммунной системы ( снижение секреции SlgA), улучшение психического стресса (снижение кортизола) и улучшает фризическое благополучие, гибкость и мышечное напряжение. ${ }^{25}$

Однако Эрлих и 25 сотрудников, Аобились улучшения спортивных результатов, повышение уровня фризического благополучия, повышение конкурентоспособной реакции, во время тренировок и игр, помогая в восстановлении мышечной способности.

Другие поражения, которые можно предотвратить с иглоукалыванием являются растяжения связок, которые влияют на связки, вызывая много болей и ограничение фрункции суставов. Франция 26, использовали точки аши (болезненные точки пальпации), связанные с мочевого пузыря 60 (рисунок 2А) для устранения боли; желчного пузыря 39, что укрепляет кости, сухожилия и борется с алгией в конечностях; и желчный пузырь 40 стимулирует Ци и Сюэ; желудка 41 (рисунок 2В), который лечит боковые изменения лодыжки и желудка 36 (рисунок 1В), устраняя обструкцию и стимулируя циркуляцию Ци и местных Xue.

Рисунок 2 A: мочевой пузырь 60 - между ахилловом сухожилием и краем бокового соленого голеностопа лодыжки, на уровне высшей точки малеолы; В: желчный пузырь 39 - 3 цуна выше высшей точки внешнего ялеола, в депрессии между малоберцовой и длинной и короткой фрибулярной сухожилия миокулярной и желчного пузыря 40 - на антеро-нижней стороне внешнего ялеола, в боковой депрессии сухожилия длинной цифровой мышцы дипрессора ; желудка 41 - в 
дозальной середине лодыжки выше крестообразной связки, между сухожилиями длинной мышцы халукс-разгибателя и длинным разгибателем пальцев.

Источник: Вэнь 17

Некоторые спортсмены могут быть удивлены растяжения связок, который определяется как травмы сухожилий шейки матки, что вызывает боль в мышцах и жесткость. Существует протокол, чтобы исправить эту проблему и вернуть спортсмена к своим обязанностям. Wadsworth ${ }^{27}$, используется в дополнение к аши точек, которые стимулируют кровообращение Ци и Сюэ, желчный пузырь 39 (рисунок 2В), желчный пузырь 20 действует в циркуляции Ци и Сюэ, расслабляющие сухожилия и смягчить боль; губернатор ousse 14 изгнания патогенного фрактора и регулирования меридиан Ци; мочевой пузырь 10; тонкий кишечник 14; желчный пузырь 21 (рисунок 3А) стимулирует кровообращение Ци и Сюэ. Если совместный блок ограничивает сгибание и расширение, используйте точку мочевого пузыря 60 (рисунок 2A). Тонкий кишечник указывает 3, легкие 7 способствовать циркуляции Ци и Хие шеи, если он имеет ограничение вращения, используйте тонкой точки кишечника 7, который истощает Taiyang меридиан руки (рисунок 3B).

Рисунок 3 А: желчный пузырь 20 - ниже затылочного края в депрессии между трапециевидными и грудин-клидомастастоидных мышц, на краю волос и желчного пузыря 21 - в равной точке между Dazhui (VC14) и плечевой акромион, 1 цун выше точки Tianilian; губернаторская ваза 14 - в середине между тернистыми процессами; седьмой шейный позвонок и первый позвонок; мочевой пузырь 10 - на уровне между шипами второго и третьего позвонков, 1,3 бокового тюна спинной средней линии, на краевой стороне трапециевидной мышцы и тонкой кишки 14 - 3 боковых цина оси позвонка; на горизонтальном уровне нижнего края тернистого процесса первого позвонка; В: легкое 7 - на медиальной стороне предплечья, 1,5 tsun выше линии запястья между сухожилиями длинной мышцы адуктора большого пальца и длинной разгибацией мышцы carporadial; тонкий кишечник 3 - локтевая сторона руки, за метакарпально-фалангайным 
суставом пятого пальца, между светлыми и темными шкурами; Тонкий кишечник 7 - 5 tsun выше запястья, на локтевой стороне запястно-ульнаровой мышцы.

Источник: Вэнь 17

Перегрузка локтевого сустава, влияет, особенно теннисистов, и может привести к блокаде Ци и Сюэ, вызывая хроническое воспаление называется эпекондилит. Точки Аши используются в регионе, пропагандируя стимуляцию Ци. ${ }^{28}$

Для лечения поражений запястья, таких как: тендинит или теносиновит большого пальца, разгибателей и сгибателей пальцев, $\mathrm{Fra}^{\mathrm{nc}} \mathrm{e} 26$, использовали точку аши, связанную с толстой кишкой 5 для разгона тепла меридиана; тонкий кишечник 5 устранения тепла и разблокировки запястья (рисунок 4А); Тройной обогреватель 4, что в дополнение к устранению тепла прекращает воспаление и толстой кишки 11 (рисунок 4В) разблокировки ци и Хие успокаивающее боль. 
Рисунок 4 А: тонкий кишечник 5 - на локтевой стороне запястья, в депрессии между пизиформой и пертнатным стилоидным процессом; Толстый кишечник 5 на задней радиальной стороне запястья, немного дистальной радиокости, где есть депрессия между сухожилиями мышцы разгибателя короткими и длинными пальцами, при растяжении и открытии большого пальца. В: тройной обогреватель 4 - на стороне надостенного запястья, в депрессии в середине подошвской складки запястья, между сухожилиями общих цифровых мышцразгибателей и цифровым разгибателем пятого пальца; толстой кишки 11 - на радиальной стороне локтя, в брахиорадиальной мышце; при сгибании локтя, в радиальной депрессии в конце кубитной линии.

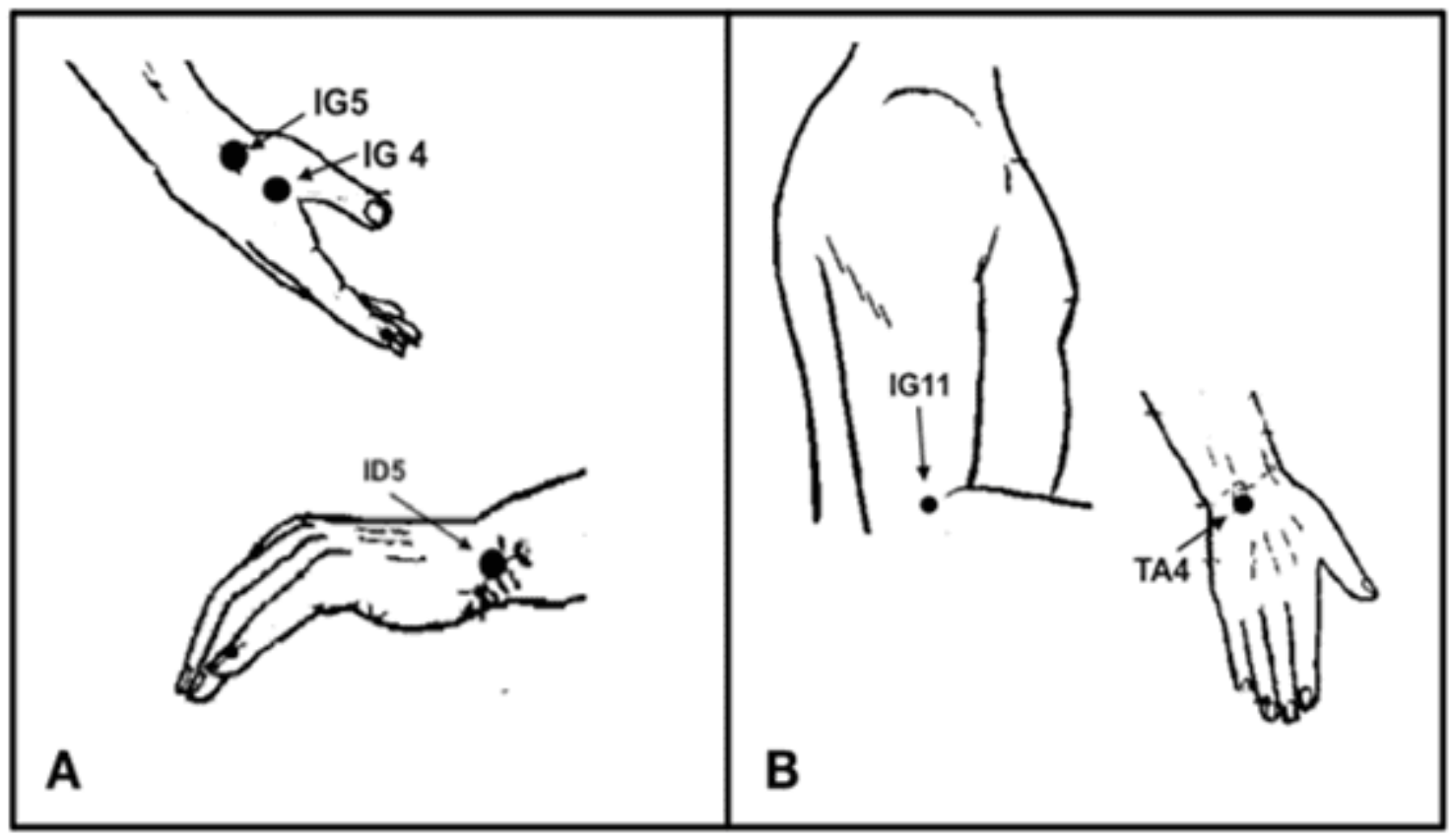

Источник: Вэнь ${ }^{17}$

Для боли в пояснице, Barela 17, связанные точк ${ }^{n}$ аши с мочевым пузырем 23 и мочевого пузыря 25, чтобы стимулировать местные Ци и Сюэ, мочевой пузырь 40 (рисунок 5), который устраняет боль и тепло.

Рисунок 5: мочевой пузырь 23 - 1,5 цуна, боковой нижний край спинного процесса позвонка (L2); мочевой пузырь 25 - 1,5 цуна, боковой нижний край спинного

Disponível em: https://www.nucleodoconhecimento.com.br/здравоохранение/иглоукалывание-впрофилактике 
процесса позвонка (L4); мочевой пузырь 40 - 3 цуна, боковая ось (Ду-Май), на нижнем уровне края во втором позвоночнике позвонка (Т2).

Источник: Вэнь 17

Теперь еще одна травма, которая беспокоит фрубольных спортсменов, являются связки, менискалей и сухожилия колена. Это лечится с аши точек, связанных с желчного пузыря 33 (рисунок 6), который расслабляет сухожилия и лечит боль; мочевой пузырь 40 (рисунок 5) устраняет боли в суставах, отек и тепло, стимулируя Ци и Сюэ; желудка 36 (рисунок 1В), регулирующего поток Ци и Сюэ меридиана, устраняющего обструкцию. ${ }^{29}$

Рисунок 6: желчный пузырь 33 - на боковом краю колена, 3 tsun выше точки yanglingquan (VB34), в верхней депрессии боковой эпитенодилок бедренной кости.

Источник: Вэнь 17

Gemeo ${ }^{30}$, заявил, что иглоукалывание может способствовать улучшению физической способности спортсменов, предотвратить и лечить травмы, которые могут возникнуть до, во время или после спортивных соревнований, в дополнение к оказанию помощи и влияющих эмоциональных фракторов, таких как тревога, раздражительность, бессонница и депрессия, которые могут непосредственно препятствовать спортивные возможности этих людей. Он разработал специальный протокол с использованием мастер точки иглоукалывания, выбирая в соответствии с модальности (График 1):

Таблица 2: Гемео ${ }^{30}$

\section{Мастер моральной губернатор ваза 19 (рисунок 7) энергии}

Disponível em: https://www.nucleodoconhecimento.com.br/здравоохранение/иглоукалывание-в- 


\begin{tabular}{|c|c|}
\hline $\begin{array}{l}\text { Мастер } \\
\text { энергии }\end{array}$ & $\begin{array}{l}\text { влияет на общую энергию, действуя на родовую и } \\
\text { послеродовую энергию - губернаторская ваза } 4,6,10 \text {, } \\
13 \text { (рисунок 7) }\end{array}$ \\
\hline $\begin{array}{l}\text { Мастера верхних } \\
\text { конечностей }\end{array}$ & $\begin{array}{l}\text { действует на движения предплечья, запястья, руки и } \\
\text { плечи: тройной обогреватель } 15 \text { (рисунок 7) }\end{array}$ \\
\hline Мастер легких & $\begin{array}{l}\text { вмешивается в переднюю грудную клетку: легкое } 1 \\
\text { (рисунок 7) }\end{array}$ \\
\hline Назад мастер & $\begin{array}{l}\text { диафррагма, дыхание и nn. фрреник: мочевой пузырь17 } \\
\text { (рисунок 7) }\end{array}$ \\
\hline Мастер живота & влияние на брюшную талию: живот 27 (рисунок 7) \\
\hline Мастер почек & $\begin{array}{l}\text { поясничной талии действует: мочевой пузырь } 47 \text { и } \\
\text { мочевой пузырь } 52 \text { (рисунок 8) }\end{array}$ \\
\hline Мастер хип-хопа & $\begin{array}{l}\text { действует мм. ягодицы и коксофеморальный сустав } \\
\text { (рисунок 8) }\end{array}$ \\
\hline Мастер бедра & $\begin{array}{l}\text { действует в мускулатуре бедер: желчный пузырь } 30 \\
\text { (рисунок 8) }\end{array}$ \\
\hline $\begin{array}{l}\text { Нижний } \\
\text { мастер }\end{array}$ & $\begin{array}{l}\text { влияет на действие ног и мышц в целом: мочевой } \\
\text { пузырь } 58 \text { (рисунок 8) и живот } 36 \text { (рисунок 1В) }\end{array}$ \\
\hline $\begin{array}{l}\text { Точки для } \\
\text { улучшения баланса } \\
\text { и отражения }\end{array}$ & $\begin{array}{l}\text { вазо зачатие 4, вазо-зачатие } 6 \text { (рисунок 9), толстая } \\
\text { кишка } 11 \text { (рисунок 4В), мочевой пузырь } 46 \text { (рисунок 8), } \\
\text { губернаторский сосуд } 4 \text { (рисунок 7). }\end{array}$ \\
\hline
\end{tabular}

Рисунок 7: губернаторская ваза 4 - в центральной линии позвоночника позвоночника; в пространстве между шипами второго и третьего поясничных позвонков; губернаторская ваза 6 - в центральной линии колонны; между одиннадцатым и двенадцатым тернистым процессом позвонков; губернатор ваза 10 - в центральной линии колонны; между шестым и седьмым тернистым процессом позвонков; губернаторская ваза 13 - в центральной линии колонны; между первым и вторым тернистым процессом позвонков; губернаторская ваза 19 - 1,5 цуна за Байхуи (VG 20); желудок 27 - 2 цуна ниже пупка и 2 тюна рядом с медиальной линией на боковом краю прямой абдоминальной мышцы; мочевой

Disponível em: https://www.nucleodoconhecimento.com.br/здравоохранение/иглоукалывание-впрофилактике 
пузырь 17 - 1,5 цуна оси, на нижнем краю уровня спинного процесса позвонка (T7); легких 1 - на антеролатеральной стороне грудной клетки, ниже точки Yunmen (P2) (яма между ключицей и плечом), в пространстве между первым и вторым ребром, 6 tsun на средней стороне линии тела; тройной обогреватель 15 - в супраскапулярной яме, между Цюань (ID13) и Цзяньцзинь (VB21).

Источник: Вэнь 17

Рисунок 8: мочевой пузырь 46 - 3 тсун, боковой оси, на нижнем краю уровня позвоночника позвонка (Т9); мочевой пузырь 47 - 3 цуна, боковая ось, на нижнем краю позвоночника (Т10); мочевой пузырь 52 - 3 цуна, боковой оси, на уровне второго позвоночника крестца, на боковом краю илиоссакрального сустава; мочевой пузырь 58 - л tsun ниже боковой стороны точки chengshan (B57); 7 tsun над пятки, на боковой стороне желудочно-кишечного сухожилия мышц; желчный пузырь 30 - в ягодице, в линии между священным перерывом и видным из больших trochanter; одна треть бокового расстояния на нижнем краю мышцы пирифрормы; дополнительная точка бедра - в середине линии, начиная от верхнего конца межглютеальной канавки до части внешнего гребня ишио.
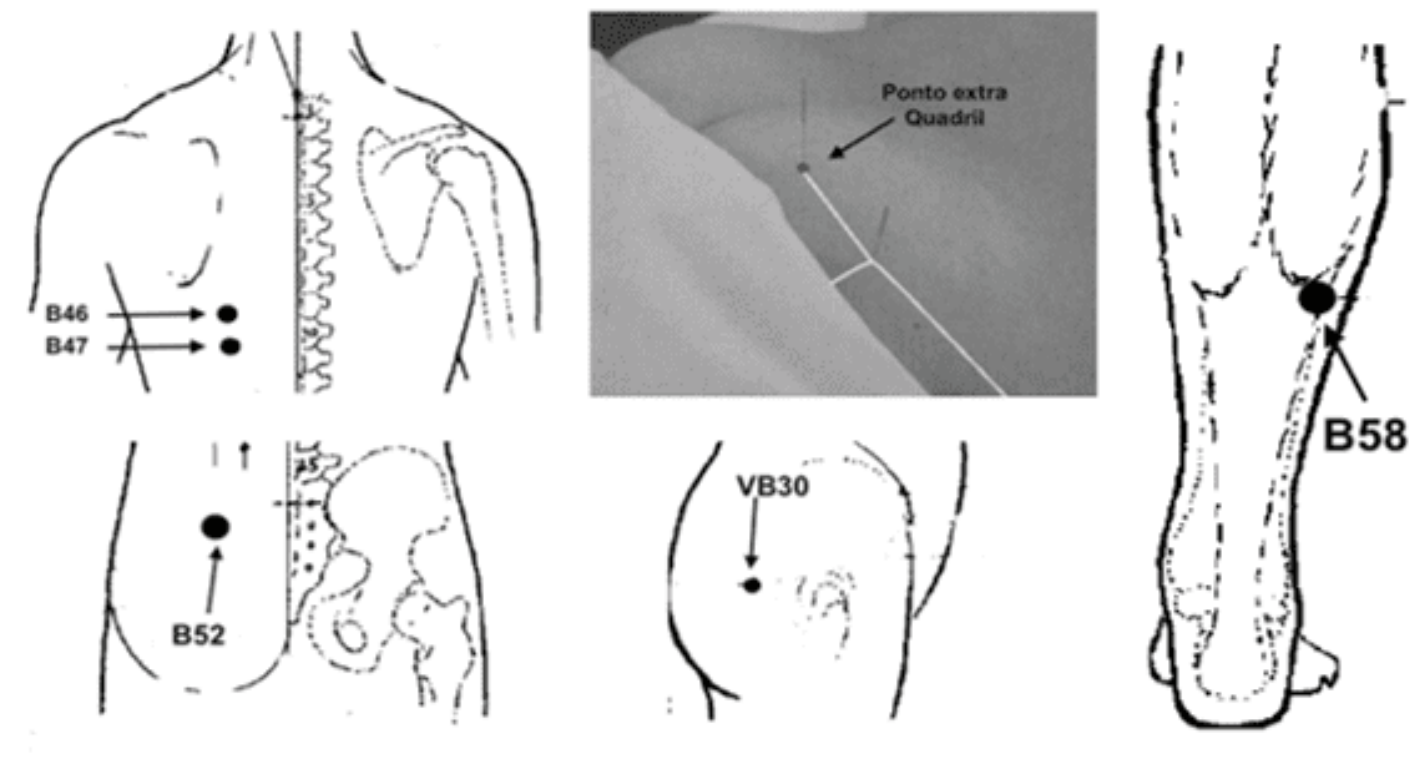

Источник: Вэ${ }^{\text {нь }} 17 ;$ Россето ${ }^{31}$

RC: 41655

Disponível em: https://www.nucleodoconhecimento.com.br/здравоохранение/иглоукалывание-впрофилактике 
Рисунок 9: ваза зачатие 4 - 3 tsun ниже пупка, в центральной линии живота; ваза зачатие 6 - 1,5 цуна ниже пупка, в центральной линии живота.

Источник: Вэнь 17

\section{АКУПЕКУРТУРА В IMPROVEMENT АТЛЕTИЯ PERFORMANCE}

При работе с иглоукалыванием в профилактике травм у спортсменов, мы не должны забывать, что достижение этой превентивной цели, следовательно, мы улучшаем качество и физическую целостность и может вмешаться в улучшение производительности.

В азиатских странах использование иглоукалывание развивает ффизическое благополучие спортсменов, регулируется нервной, эндокринной, иммунной системой и, как следствие, улучшение фризического состояния в нескольких условиях. ${ }^{32,31,34}$ Кроме того, есть очки, применяемые до, во время и после тренировок и игр, которые помогают в поддержании мышц, таких как снижение молочной кислоты, снижение боли, усталость, ускорение восстановления и улучшения производительности. ${ }^{35}$

Иглоукалывание стимулирует высвобождение биохимических веществ, что снимает мышечную усталость от интенсивных упражнений, помимо поощрения повышенной антиоксидантной активности, снижение окислительного стресса. Во время исследования, спортсмены получили лечение с электроакупунктуры в течение 30 минут, в течение 30 дней, и в результате было значительное увеличение супероксид дисмутазы (SOD) и снижение malondial крови (MDA). Superoxide dismutase является фрерментом с антиоксидантным действием, который защищает клетки от токсичных веществ, прилагая мощный противовоспалительный ответ в организме. MDA связано с воспалительными и дегенеративными заболеваниями, что позволяет исследователям сделать вывод, что электроакупунктура снижает скорость MDA и увеличивает SOD, способствуя снятию усталости и улучшению фризической работоспособности. ${ }^{36}$ 
Хотя это тысячелетний метод, его использование улучшает фризическую и умственную работоспособность спортсмена в последнее время. Луна, опубликовал исследование, демонстрирующее, что иглоукалывание статистически улучшили максимальную прочность и потенцию спортсменовспринтеров (100, 200 и 400 метров мелкой без барьеров) и с тех пор исследования в этом отношении были углублены. ${ }^{37}$

В исследовании, Сантос ${ }^{2} 0$ использовали мужчин Handbol спортсменов в возрасте от 15 до 17 лет, где он выполнил два 100-метровых выстрелов в каждого спортсмена (до иглоукалывания). После 45 минут применения протокола, выбранного для лечения, он переоценил таким же образом. Выбранные очки были: мочевой пузырь 58 (рисунок 8) мастер ног и ног; желудок 36 (рисунок 1В) тонизирует полосатую мускулатуру и используется для потенцировать лечение; дополнительная мастер-пойнт бедер (рисунок 8) тонизирует ягодицы и повышает гибкость коксофеморального сустава; желчный пузырь 30 (рисунок 8) мастер бедер и способствует гибкости для движения нижних конечностей; легких 1 (рисунок 7) мастер легких способствует эфффективной дыхательной работы; мочевой пузырь 17 (рисунок 7) мастер спины, спинной диафрагмы шу и точки сюэ влияния, которая регулирует дыхательный ритм; тройной теплее 15 (рисунок 7) мастер оружия, который командует суставной группы мышц плеч, затылка, шейного отдела позвоночника, первые шесть грудных позвонков, рук, предплечья, запястья и руки.

Результаты показали значительное улучшение, с уменьшением времени во второй батарее 100-метровых испытаний. Среднее улучшение в разы составило 5,72\%, а спортсмен с достигнутыми лучшими показателями достиг 10,84\%.

Это в среднем 5,72\%, достигнутые в улучшении производительности кажется небольшим, но если сравнивать с результатами важных соревнований, мы можем видеть обоснованность практики: на Панамериканских играх в Рио-деРазница между 1-м и 8-м была 0,23 секунды, что представляет собой время на

Disponível em: https://www.nucleodoconhecimento.com.br/здравоохранение/иглоукалывание-в- 
2,26\% выше, то есть, если этот спортсмен добился улучшения 5,72\% в его исполнении, он, вероятно, получить другие результаты.

Существует мало научного внимания, когда мы лечим, иглоукалывание эффректы на улучшение фризиологической реакции, вызванной фризическими упражнениями и несколько направленных на высокую производительность спортсменов. ${ }^{24,38}$ Но Россетто 31 представляет протокол для улучшения спортивных результатов в футболе и регби, используя следующие точки: мочевой пузырь 52 и мочевой пузырь 58 (рис. 8); мочевой пузырь 17 и легких 1 (рисунок 7).

Мочевой пузырь точки 58, тонизирует полосатые мускулатуры всего тела, сустав колени, лодыжки и ноги. Это важный момент, чтобы избежать усталости, особенно если используется с желудком 36. Мочевой пузырь 17 тонизирует мышцы позвоночника, связок суставов и даже повышает гибкость самих позвоночных суставов, способствуя регулятивным действиям на диафрагму, дыхательный ритм и фрреники. Мочевой пузырь 52 тонизирует всю область поясничных мышц и способствует силе воли. Легкие 1 используется, чтобы сделать дыхательную работу эффективной и связано с супраклавикулярных и межреберных нервов (с более глубоким вставки) оказание помощи в брахиальной сплетения. Использование с точки мочевого пузыря 17 узаконивает дыхательный ритм.

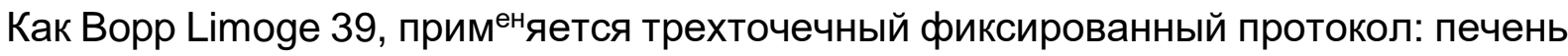
5 (рисунок 10), тройной обогреватель 15 (рисунок 7) и мочевой пузырь 58 (рисунок 8), добавленный к двум другим случайным точкам, плацебо, в 35 спортсменов, достижение значительного улучшения спортивных результатов лиц, проверенных. 
Рисунок 10: печень 5 - 5 цун выше медиальный маэлолус; на постеромедийном краю голени.

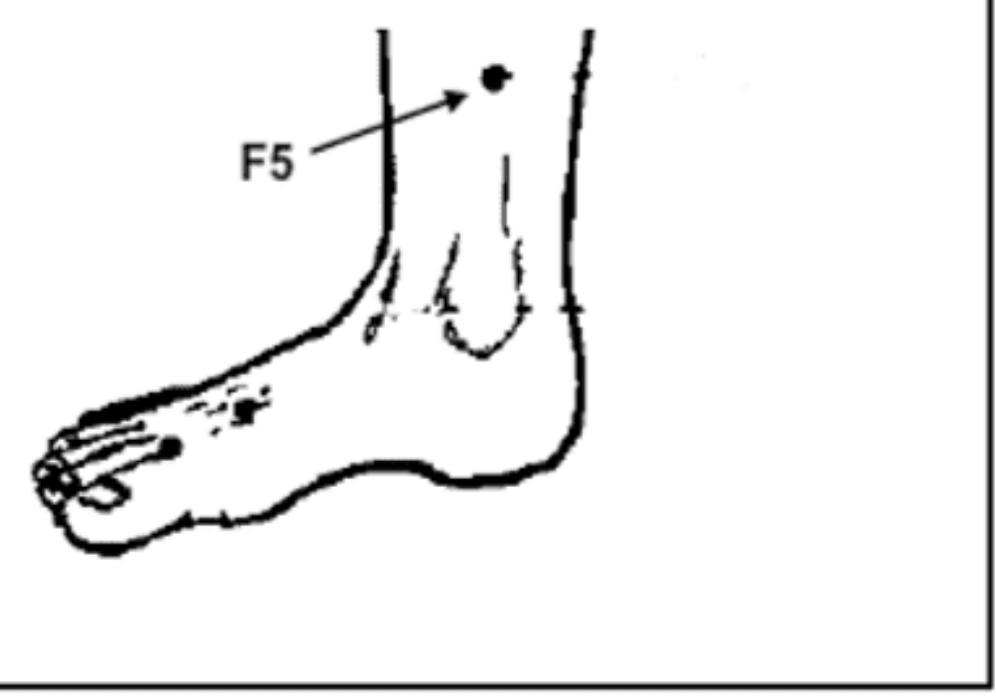

Источник: Вэнь ${ }^{17}$

Исследование Akimoto ${ }^{38}$ подтверждает результаты нескольких исследований, связанных с улучшением фризических и умственных способностей, где он протестировал двадцать один фрутбольный спортсмен во время этапа соревнований, биохимически оценки слюнных $\lg A$ и кортизола, по скорости мышечное напряжение и усталость, что приводит к увеличению кортизола и снижения слюны $\lg \mathrm{A}$, подтверждающие эфффективное улучшение спортивных и психических работоспособности.

В другом исследовании проводится в лечении спортивных травм с кинетической акупунктурой (связь иглоукалывания с кинезиотерапией), у спортсменов тенниса, фрутбола, волейбола, олимпийской гимнастики, капоэйры, тюка и джиу-джитсу; пациенты с локомотивными расстройствами, такими как: ахиллесовый тендинит, боли в пояснице, боли в спине, праркиколо, теносиновит, синдром запястного канала, синдром пронадора, ушиб мышц, теннисный локоть и гоналгия из-за травмы мениска. Все 31 проверенный спортсмен вернулся к тренировкам,

Disponível em: https://www.nucleodoconhecimento.com.br/здравоохранение/иглоукалывание-впрофилактике 
максимум до третьей сессии: 53\% вернулись после первой сессии; 37\% после второго; 11\% после третьего, заключив, что эта техника действовала эфрфективно ускоряя время восстановления спортсменов. Объяснением этого является то, что иглоукалывание действует в ингибирование спазмов цикла боль, ведущая к сегментарному аффрерентному блоку, супраспинальному нисходящему блоку, через пирамидальные пути и активацию процесса эндогенных анальгетиков. ${ }^{26}$

В другом исследовании в переходный период оценивались переменные максимальной прочности, взрывной силы, анаэробного сопротивления и скорости в высокодоходных спринтерских коридорах. Меридиан печени был сорокусирован: печень 1; печень 3; печень 8 (рисунок 11A), потому что энергетические функции этого органа для хранения крови, контроля дисперсии, дренажа и определить сухожилия и связки условиях, в дополнение к контролю эмоциональной части, потому что энергетический дефицит может вызвать: депрессия; раздражительность; бессонница; тревожные сны. Первый проколотый acupoint был мочевой пузырь 62, желчный пузырь 34, почки 3 (рисунок 11В), а затем поджелудочной железы селезенки 3 (рисунок 1A), печень 1, печень 3, печень 8 (рисунок 11А), желудок 36 (рисунок 1В) и закрытие с тонкой кишки 3 (рисунок 3В). Печень стежки были введены в восьмой сессии. Результаты были положительно результативные, что развивало улучшение исследуемых функций. 24

Рисунок 11 А: печень 1 - 0,1 цуна выше бокового угла ногтевого ложа ногтя и печени 3 - между первой и второй плюсневой, за плюснево-фалангаальными суставами; печень 8 - в конце медиальной стороны поплит-складки, на антеромедиальном краю полумембраозных и полутендиновых мышц. В: почка 3 - между задним краем медиального малеола и ахиллова сухожилия; желчный пузырь 34 - л tsun ниже колена, в передней и нижней депрессии головы малоберцовой кости, в фасции длинной перореаной мышцы; bexia 62 - 0.5 tsun ниже внешнего ялеола, при нижней депрессии малеола.

Disponível em: https://www.nucleodoconhecimento.com.br/здравоохранение/иглоукалывание-в- 
Источник: Вэнь 17

Эрлих 25, с Другой стороны, разделил 36 мужчин лиц на три группы: один лечение с системной иглоукалывание; другая контрольная группа; другой с плацебо иглоукалывание. Значительное улучшение фризической работоспособности и гемодинамических параметров было получено. Одна сессия проводилась в неделю в губернаторских вазо 20, вазо зачатие 15 и печень 13, мочевой пузырь 43 (рисунок 12), желудок 36 (рисунок 1В) и селезенки поджелудочной железы 6 (рисунок 1А) в течение 5 недель. Они проанализировали, что анаэробный порог улучшился на 6,62\%, а максимальная производительность в 7,15\% в группе, получившую системную иглоукалывание, уже в контрольной группе и плацебо, не было никаких изменений.

Рисунок 12: губернаторская ваза 20 - на центрально-вертикальной головной линии; 7 tsun над задним краем волос; 5 tsun за передней края волос; вазо зачатие 15 - 3 цуна выше Чжунвана (RM12), в центральной линии живота и печени 13 - на нижнем краю конечной точки одиннадцатого ребра, на стороне живота; мочевой пузырь 43 - 3 цуна, боковая ось (Ду-Май), на нижнем краю уровня позвоночника позвонка (Т5).

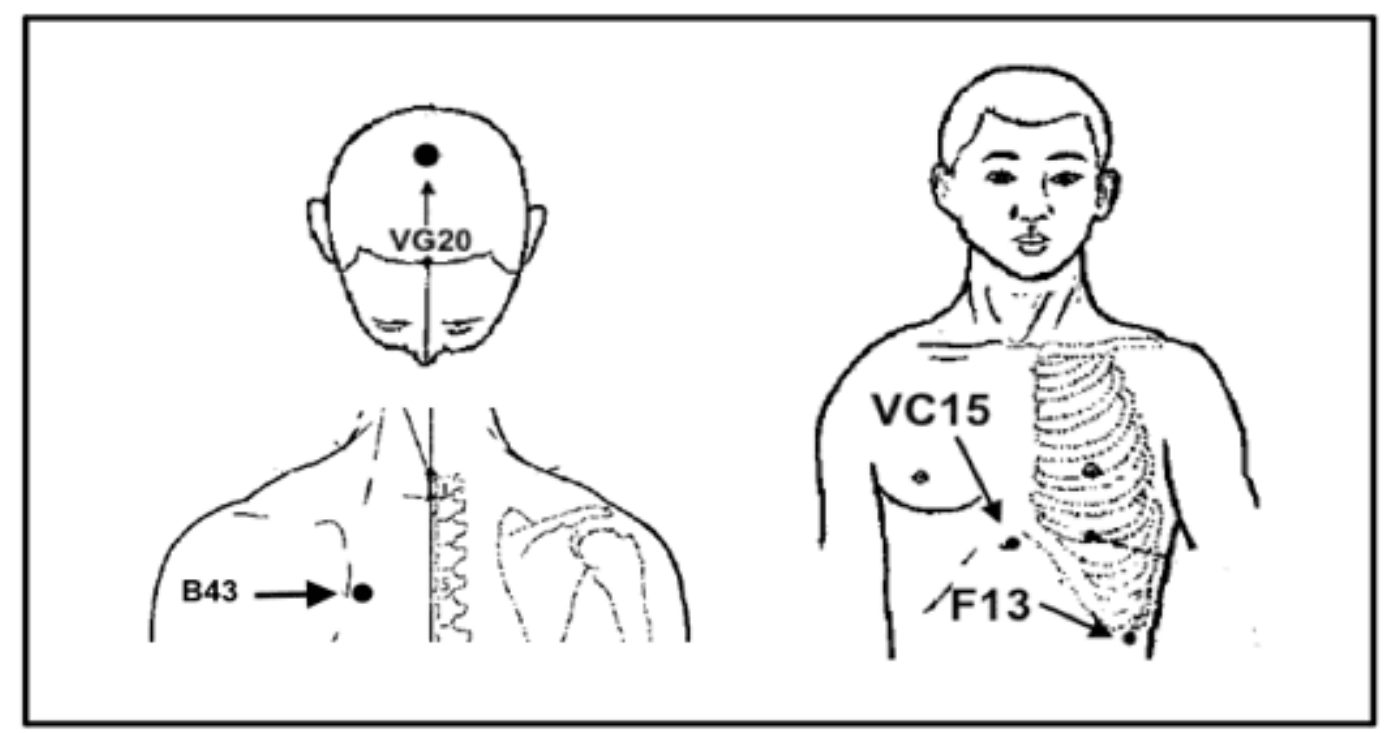

Источник: Вэнь ${ }^{17}$

Disponível em: https://www.nucleodoconhecimento.com.br/здравоохранение/иглоукалывание-впрофилактике 
Лин ${ }^{40}$, оценили влияние ушной иглоукалывание на частоту сердечных приступов (Cmf), потребление кислорода (VO2max) и молочной кислоты в крови спортсменов в элитных баскетбольных спортсменов. Они были разделены на 2 группы по 12 спортсменов каждая, где: Группа 1 - аурическая иглоукалывание; Группа 2 - контроль. Каждый из спортсменов ездил на велосипеде до истощения, и Cmax, VO2max и молочной кислоты крови были измерены в период отдыха, после нагрева и во время физических упражнений: после 5, 30 и 60 минут. Результаты показали, что HR и молочная кислота в крови были значительно ниже, чем в контрольной группе, после 30 и 60 минут активности.

Тот же автор, Лин 41, в новом исследовании, оценилте те же переменные, что и FCm'x, VO2max и молочная кислота крови в 30 баскетбольных спортсменах, разделенных на 3 группы: 1-системная иглоукалывание; 2-х фиктивная группа; 3контроль. В группе 1 использовалась точка циркуляции и сексуальности 6 (рисунок 13), желудок 36 (рисунок 1В), и во время исследования каждый спортсмен проводил тесты на беговой дорожке в течение 15 минут. Переменные были измерены в отдыхе и через 5, 30 и 60 минут после тренировки, получив значительное сокращение трех переменных после 30 и 60 минут.

Рисунок 13: циркуляция и сексуальность 6 - 1 цун ниже точки цзянси (PC5); 2 цуна над запястьем, между сухожилиями длинных мышц пальма и кистеворадиальным сгибателем

Источник: Вэнь 17

Диллон 42, оценил производительность 20 мужчин велосипедистов, подразделяются на три группы: лечение системной иглоукалывание: желудок 36 (рисунок 1В), желчный пузырь 34 (рисунок 11В), печень 11 (рисунок 14), почки 3 (рисунок 11В), губернатор судна 20 (рисунок 12 ); фриктивная иглоукалывание; контроль, без вмешательства. Спортсмены проехали на велотренажере на 20 км на максимальной поддерживаемой скорости. Аналоговая шкала боли, визуальные, для нижних конечностей, индуцированных упражнениями;

Disponível em: https://www.nucleodoconhecimento.com.br/здравоохранение/иглоукалывание-впрофилактике 
Масштабы воспринимаемых усилий боргов; после тренировки концентрации лактата крови. Группа, индуцированная акупунктуры, представила более высокий балл в шкале боргов, что означает, что лечение способствовало большему усилию во время деятельности и уменьшило время завершения теста.

Рисунок 14: печень 11 - 1 цун ниже ингинала; на антеро-медиальном краю порога длинной мышцы аддуктора

Источник: Вэнь 17

По данным Hubscher ${ }^{4} 3$, он оценил максимальный прыжок с биподальной посадкой и добровольной максимальной изометрической силой четырехглавой, с поверхностной электромиографией для измерения активности мышц бедренной прямой кишки в течение 30 секунд поддержки. Тридцать три спортсмена были разделены (13 женщин и 20 мужчин) на три группы: системная иглоукалывание с использованием очков желудка 36 (рисунок 1B), селезенка поджелудочной железы 6 (рисунок 1А), вазо зачатие 6 (рисунок 9); акупунктура группы с несуществующими точками; Контрольная группа использовала лазерное отключение. В результате выяснилось, что это было незначительное увеличение максимального скачка, но значительное увеличение изометрической силы четырехглавой.

В другом исследовании $\mathrm{Ge}^{\mathrm{ng}} 44$, он набрал 12 здоровых мужчин с учащимися фризического воспитания в возрасте от 19 до 25 лет, оценивая влияние иглоукалывания уха на уровни молочной кислоты в крови, вызванные фризическими упражнениями на беговой дорожке (V02max). Он выбрал точки: печень, легких, subcortex, эндокринных желез и тройной обогреватель (рисунок 15). Результатом было увеличение в здании емкости кислорода и снижение уровня молочной кислоты в крови после упражнений. 
Рисунок 15: Очки уха

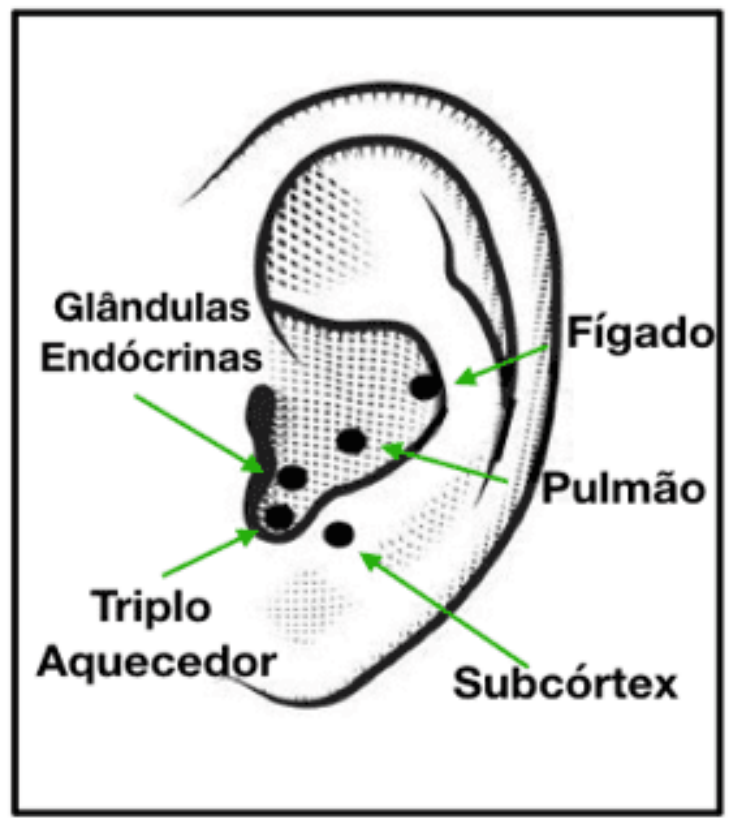

Источник: Личный архив автора

Другое исследование 28 мужчин, разделенных на контрольную и экспериментальную группу. Сбор данных был выполнен до сеансов иглоукалывание: Измерение базальной частоты сердечных колец, через оксиметр; измерение частоты сердечных приступов после фризического тестирования в Гарвардском банке, с высотой 50 см, выполнение подъемов и спусков в течение 5 минут; частота сердечных приступов измеряется за полторы минуты теста, 2 с половиной минуты и 3 с половиной минуты; расчет индекса фризической подготовки (IAF); средняя частота сердечных приступов и количество подъемов и спусков во время тестирования Гарвардского банка. Были использованы точки: легочная 10 и вазо-зачатие 17 (рисунок 16), тонкий кишечник 3 (рисунок 3В), для того, чтобы тонизировать и привести к расслаблению мышц, укреплению сухожилий, поясничного отдела позвоночника и нижних конечностей. В точках желчного пузыря 34 (рисунок 11В), селезенка поджелудочной железы 4 и почек 7 (рисунок 16) были связаны с седканцией, чтобы потенцировать движение кровообращения (Xue) и лимфа (Jing Yie). Было

Disponível em: https://www.nucleodoconhecimento.com.br/здравоохранение/иглоукалывание-впрофилактике 
проведено восемь сеансов, по одной в неделю, и результаты не показали существенного улучшения по отношению к частоте сердечных приступов и фризической подготовке. В повышении фризической производительности, подъемы и спуски из Гарвардского банка, значения были значительными для экспериментальной группы по отношению к контролю. ${ }^{36}$

Рисунок 16: легкое 10 - на палмарной стороне, над суставом первого цифрового метакарпа, между темными и светлыми шкурами; ваза зачатие 17 - в средней линии грудины на уровне соска; почка 7 - 2 tsun выше Тайси (R3); на антеромедиальном краю единственной мышцы; селезенка поджелудочная железа 4 на медиальной стороне стопы; 1 tsun за плюсневой сустав, на стыке темной и светлой кожи.

Источник: Вэнь 17

Фонсека 45, с другой стороны, использовали образец с 40 мужчин лиц, практикующих напряжение мышц две группы: контроль и вмешательство для оценки влияния иглоукалывание на локализованную мышечную выносливость (RML) верхних конечностей. Контрольная группа была представлена на тест RML в течение 1 минуты, проходя период отдыха в 30 минут и после, тест был повторен.

В интервенционной группе был применен тест: тест; отдохнул в течение 5 минут; применение иглоукалывания, тонирование точек: селезенка поджелудочной железы 3 (рисунок 1А); почка 7 (рис. 16); желудок 36 (рисунок 1В); губернаторская ваза 4; тройной обогреватель 15 (рисунок 7); в течение 25 минут. После применимости, RML тест повторяется, в результате чего значительное улучшение мышечной производительности группы вмешательства.

В 2015 году Мониз использовал 12 регбистов, где они были распределены в контрольной группе и тестовой группе, выполняя иглоукалывание в течение 20 минут в точках: сердце 5, мочевой пузырь 15, мочевой пузырь 44 (рисунок 17) и кровообращение и сексуальность 6 (рисунок 13). Во второй еженедельной сессии

Disponível em: https://www.nucleodoconhecimento.com.br/здравоохранение/иглоукалывание-впрофилактике 
проколы выполнялись в точках стресса и триггерных точках. Результаты ясно предложили что применение иглоукалывание приносит преимущества к спортсменам над проблемами мышцы, с полным спасением на уровне боли и ограничением движений перед затем сыграть ушиб.

Рисунок 17: сердце 5 - на брюшной и локтевой стороне предплечья, на локтевой стороне сухожилия запястью локтевого сгибателя мышц; 1 tsun выше ручки; мочевой пузырь 15 - на нижнем краю спинного процесса позвонка (T5), на той же вертикальной линии, что и точка Фейшу (В13); мочевой пузырь 44 - 3 цуна, боковой оси, на нижнем краю уровня позвоночника позвонка (Т6).

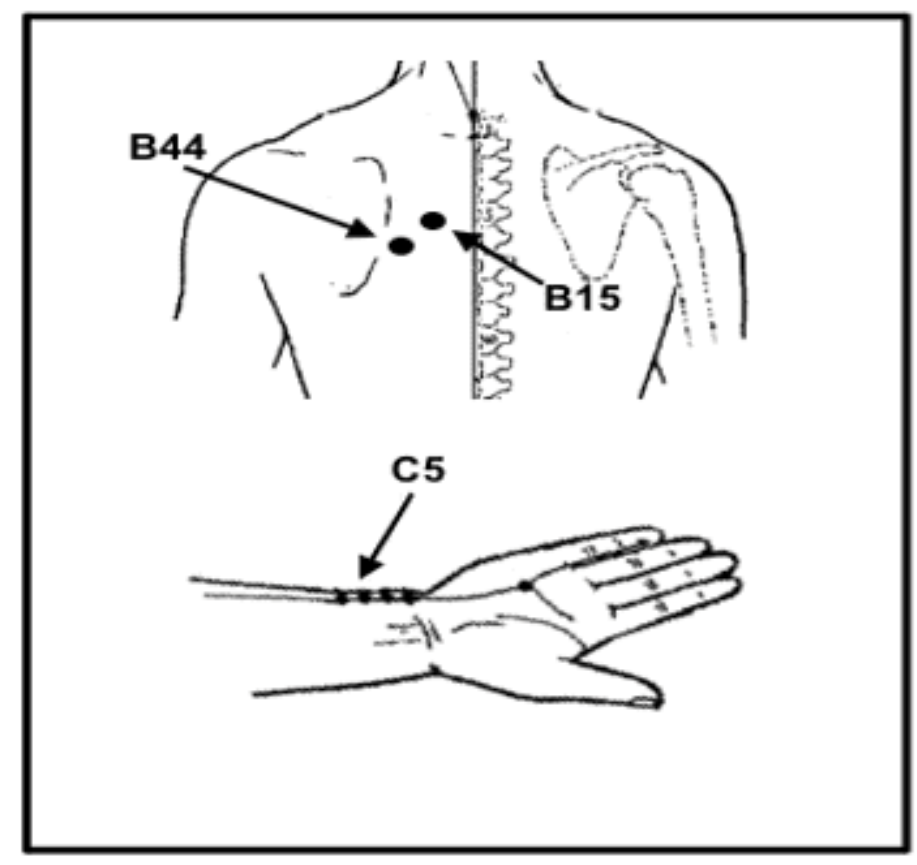

Источник: Вэнь ${ }^{17}$

Большинство исследований показывают значительные результаты в отношении улучшения фризической работоспособности, что приводит к улучшению во время окончания испытаний. Это вызывает лиц, представленных на лечение иглоукалыванием, получая активацию нейрофизиологии контроля боли, 
вызывая улучшение мышечной производительности, в значительной степени влияющих на конечный результат. ${ }^{46}$

\section{АКУПЕКУРСТВО В ОБРАБОТКе ЛЕСИОНОВ}

Иглоукалывание действует в этом процессе лечения болезни, устраняя ее причину, и, таким образом, в настоящее время вводят как для лечения различных острых и хронических болей. Его можно применять в хирургических процедурах, в улучшении фризических кондиционных условий и в профрилактике травм в различных видах спорта. ${ }^{24}$

В настоящее время спортсмены и их тренеры стремятся к улучшению физической работоспособности и профилактики путем исчерпывающей подготовки, мониторинга питания, фризиотерапевтической профилактики, планов обучения, психологического мониторинга и использования новых спортивного оборудования достижения целей. Даже с этими усовершенствованными системами, многие спортсмены предпочитают и двигаться по самому быстрому пути, используя незаконное лечение, такие как использование анаболических стероидов и наркотиков. ${ }^{32}$ Согласно Frasca ${ }^{35}$, он заявляет, что иглоукалывание работает в человеке в целом, лечение боли, улучшение производительности и действует непосредственно в психологической системе спортсменов генерации увеличение психической уверенности спортсмена.

По словам Сантоса и сотрудн ${ }^{\text {ик } о в ~ 20, ~ б о л ь ш и н с т в о ~ с п о р т с м е н о в ~ и м е л и ~ о п ы т ~}$ ощущения позднего начала мышечных болей, которые появляются в тренировочные периоды, где интенсивность и объем работы выше. Другой тип боли вызван травмой, отодвигая спортсменов от тренировок и соревнований на длительные периоды. ${ }^{21}$

Основываясь на нейрофизиологии, гистонатомической и нейрохимической, СТМ объясняет, что, punturating точки, которая находится в каналах конкретных меридианов, это будет способствовать поток энергии в этих структурах перегружены спортивных условий, достижения обезболивающих целей. ${ }^{25,47}$

Disponível em: https://www.nucleodoconhecimento.com.br/здравоохранение/иглоукалывание-впрофилактике 
Другие авторы сообщают, что применение метода имеет действие эндогенных опиоидов, высвобождение эндорфина, который определяется при болевой модуляции и ингибировании ноцицептивной передачи на всех уровнях нервной системы происходит.) через использование электроакупунктуры, положительное регулирование выражения соотношения синтеза оксида азота нервной азота (nNOS) / NADPH diaphorase (NADPHd) происходит. Есть также некоторые данные, свидетельствующие о том, что в дополнение к опиоидам, другие механизмы участвуют в лечении боли. 6, 48, 49, 50, 51

Наличие NO способствует улучшению местной васкуляризации, что свидетельствует о домашнем действии иглоукалывание, но увеличение NO в ледяной фрасцикл может прояснить это нормативное действие соматических рефлексов, вызванных техникой. 6, 52 Другие исследования наблюдают высвобождение серотонина после стимуляции иглы. $51,52,53$

Иглоукалывание применяется для тонуса, расслаблять мышцы спортсменов и поддерживать энергетический баланс тела. В дополнение к обезболивающим эффектом, можно стимулировать другие биологические фракторы, активируя гипоталамус и гипофиз, достигающие системных эффректов, таких как: увеличение нейрогормонов и нейротрансмиттеров.2 улучшение производительности спортсмена в их соответствующих условиях, таким образом, контролируется системами, нервной, эндокринной и иммунной. $36,54,55$, 56, 57, 58, 59, 60 Многие исследования показали, что иглоукалывание действует в этих трех системах, обеспечивая: облегчение напряженности и мышечной боли; увеличение местного кровотока; высвобождение эндогенных опиоидов, снижение восприятия боли; улучшение модуляции симпатического и парасимпатического баланса нервной системы; модуляция иммунной системы; активация соединительной ткани и мышц, высвобождающих миозины, которые оказывают противовоспалительные эффекты, высвобождая антиоксидантные вещества, уменьшая окислительный стресс; веществ, которые имеют вероятные эргогенные эффректы. 5, 13, 61, 62, 63, 64 
В лабораторном исследовании с крысами, Ли и коллаборационист ${ }^{\text {ов }}, 65$ сообщил, что животное при представлении на иглоукалывание и упражнения представлены подавление воздействия на 5 HТ (5 гидрокситриптаминов) и выражение THP (гидроксилаза триптофран) в арсальном rafe морских свинок, достигая эргогенного эфрфекта, так как 5 HТ предотвращает выполнение упражнений у людей и крыс.

В одном исследовании, Зилони и 66 сотрудников сообщили, что можно найти различные активности в головном мозге, с помощью магнитно-резонансной оценки, во время процедуры иглы. Эти изменения появляются в таких регионах, как: эпиакедурального серого вещества, гипоталамуса, первичной соматосенсорной коры, верхней височной извилины, ростральной передней цингулировать кору и медиальной области затылочной коры. ${ }^{48}$

В своем исследовании, Minori 67 лечение повторяющихся травм плеча стресс, с сочетанием замечательных стежков сосуда: тройной обогреватель 5 - желчный пузырь 41 (рисунок 18), которые используются для хронической боли и тонкой кишки 3 (рисунок 3В) - мочевой пузырь 62 ( Рисунок 11В) при острой боли.

Рисунок 18: тройной обогреватель 5 - 2 tsun над складкой запястья, между сухожилиями общей цифровой мышцы разгибателя и пятой цифрой самой мышцы; желчный пузырь 41 - при депрессии между четвертой и пятой плюсневой.

Источник: Вэнь 17

Местные точки для лечения являются: толстый кишечник 5 для боли в запястье; толстая кишка 4 снимает боль и отеки (рисунок 4 A); тонкая кишка 9 боль в руке; тройной обогреватель 14 показан для боли и воспаления плеча; толстой кишки 14 (рисунок 19) используется для жесткости, парез, снижение подвижности плеча. Дистанционные точки, боль в верхнем и передней плечах: желудок 36 для рассеивать внешние патогенные факторы; желудка 37 показаны для боли, чувствительности и нарушения кровообращения; желудок 41 устраняет влагу,

Disponível em: https://www.nucleodoconhecimento.com.br/здравоохранение/иглоукалывание-впрофилактике 
застой, ветер и успокаивает шен (ум); желудка 38 устраняет острую боль и нарушения плечевого сустава (рисунок 1В). Для задней и превосходной боли в плече: желчный пузырь 34 показан для снижения подвижности, спазмы, нарушения кровообращения и функциональные расстройства мышц и сухожилий; желчный пузырь 38 рассеивает ветер и высвобождает тепло, активирует меридиан и его сосуды (рисунок 11В). Боль лопатой, с другой стороны: мочевой пузырь 65 пацифис и укрепляет дух, освобождает тепло и снимает боль; мочевой пузырь 64 подавляет спазмы и расслабляет сухожилия; мочевой пузырь 60 снимает боль и активизирует меридиан ные и эмоциональные точки (рисунок 2A); мочевой пузырь 18 способствует общему спокойствию и устраняет спазмы (рисунок 19) и печени 8 расслабляет сухожилия (рисунок 11А).

Рисунок 19: тонкий кишечник 9 - в посттеро-нижней области плечевого сустава, на посттенонижнем боку большей круглой мышцы; тройной обогреватель 14 - в депрессии между ахромическим и большим туберкуло плечевой кости, на краю инфраспинального сухожилия; толстый кишечник 14 - покрывает боковую сторону и некоторые радиальные руки, в дистальной точке дельтоидной мышцы, 3 tsun ниже точки jianyu; мочевой пузырь 18 - на той же вертикальной линии, что и гешу (B17), на нижнем краю уровня спинного процесса позвонка (Т9).

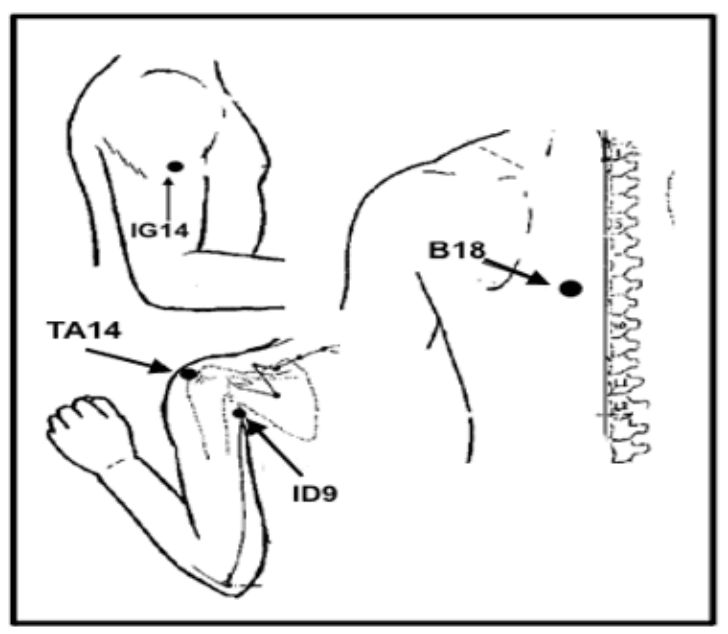

Источник: Вэнь ${ }^{17}$

Disponível em: https://www.nucleodoconhecimento.com.br/здравоохранение/иглоукалывание-впрофилактике 
Brum 68, с другой стороны, связанные в его исследовании для лечения пириформного синдрома, массаж и иглоукалывание методы в коридорах, с тем чтобы улучшить функции мышц, гибкость и облегчение симптомов. В исследовании приняли участие спортсмены обоих полов в возрасте от 30 до 60 лет. Сеанс был посвящен массажу (Шиацу) в начале, чтобы освободить стрессовые точки ягодичной и области бедра на пораженной стороне, а затем иглы, а следующим образом: по часовой стрелке; анти-время; углубление; поверхностизация иглы в следующих областях: происхождение и вставка пириформной мышцы (тазное лицо крестца и больший трокантер бедренной кости); происхождение среднего ягодичного (боковое лицо подвздоха); верхний предел минимальной ягодицы; верхний предел ягодичного максимума; происхождение мышц подколенного сухожилия (ишиатизатная туберозность); бедренная бицепс мышцы и полутендинатная мышечная дифиза, закончил с массажем.

Результаты показали значительное улучшение, когда связано с улучшением боли, гибкость, боль пальпации в мышце пириформной и тест на пириформный синдром. Это показывает соглашение с исследованием Hongwe ${ }^{\text {n }}$ 69, где эфрфективность иглоукалывания составила 97,33\% и с исследованиями Франции 26, которые связаны иглы с кинезиотерапии достижения облегчения симптомов, потенциал нервно-мышечной системы, обеспечение более быстрого возвращения к спортивным мероприятиям.

В своей работе, Роша 70, проверил улучшение активации кривой мышцы, через электромиографию, после стимуляции точки иглоукалывания желудка 45 (рисунок 20). В общей сложности 10 участников (5 мужчин и 5 женщин) были отобраны, где они выполнили упражнение 2 приземистые повторения, где они выбрали самый высокий индекс активации мышц среди двух движений по электромиографическому сигналу. Затем была применена иглоукалывание, тонирование точки желудка 45 в течение 10 минут, а затем изометрический приземистый был повторен в нижней фразе. Согласно результатам, обнаруженным иглоукалывание мгновений изменил электрическую активность

Disponível em: https://www.nucleodoconhecimento.com.br/здравоохранение/иглоукалывание-впрофилактике 
плодовой прямой мышцы во время изометрической фразы в нижней фразе приземистый, доказав, эфффективно.

Рисунок 20: живот 45 - 0,1 цуна на боковом углу ногтевого ложа второго носка

Источник: Вэнь 17

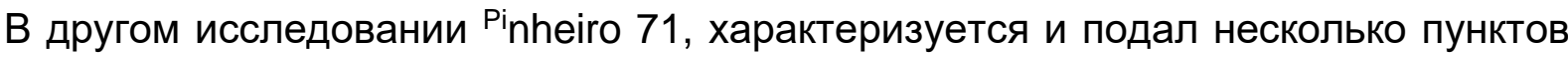
для лечения мениска поражения: печень 8 (рисунок 11А) используется для тон печени канала с функцией гармонизации и тонизации печени и крови Ци, содействие полноте почек и приводит к расслаблению сухожилий и мышц, укрепляя lq колена. Точка мочевого пузыря 40 (рисунок 5) находится в popliteal ямке, позволяющей: рассеивание тепла и порочный ветер конечностей; расслабление мышц и сухожилий; разрушение кровеносных сосудов; уменьшает тепло и устраняет застое крови; уменьшается регидес и укрепляет колено и поясничный отдел. С другой стороны, точка почки 10 (рисунок 21) мобилизует воду; тоны инь Ци; изгоняет влагу и порочное тепло, лечение боли в колене, отек ног и онемение колена и popliteal cessum.

Рисунок 21: почка 10 - на медиальной стороне поплитриальной складки, между полутендиновыми и полумембраными мышцами

Источник: Вэнь 17

В исследовании на плечевой дисфункции, Nunes $7^{2}$, рассмотрел библиографию и подал точки замечательных сосудов: тонкой кишки 3 (рисунок 3В) - мочевой пузырь 62 (рисунок 11В) для баланса функций, расслабляющие мышцы и сухожилия; точки тройного обогревателя 5 - желчного пузыря 41 (рис. 18) снимают боль и расслабляют сухожилия; Аши указывает; печень 8 (рисунок 11А) и почки 7 (рисунок 16) для укрепления сухожилий; желудок 36 (рисунок 1В) исключая холод и влагу из суставов; кишечник 4 (рисунок 4A) и толстая кишка 15 (рисунок 22), действующие при движении и боли сгибания плеч; тройной 
обогреватель 14 (рисунок 19) и толстой кишки 16 (рисунок 22) улучшения расширения мобильности и боли.

Рисунок 22: толстая кишка 15 - на верхней части плеча, на боковом краю акромиона, есть две депрессии, эта точка находится в передней депрессии; толстой кишки 16 - в депрессии между верхней и задней кромкой акромиоклавикулярного сустава и позвоночника лопатки.

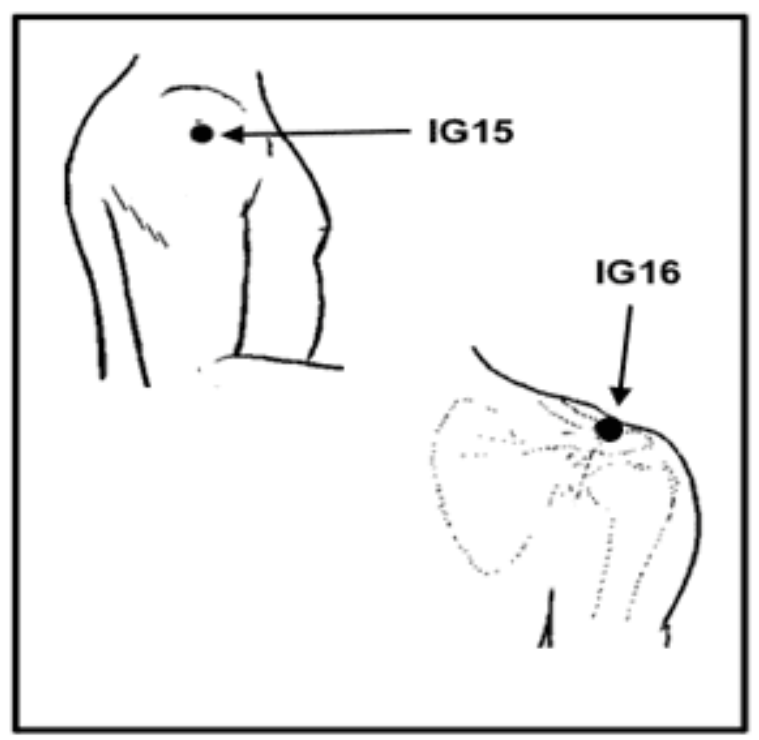

Источник: Вэнь ${ }^{1}$

Для того, чтобы проверить непосредственное воздействие иглоукалывание на позднее начало мышечной боли (DMIT) и сократительной функциональной способности мышц, Parisoto 73, выбранных 30 субъектов (12 мужчин и 18 женщин), в возрасте от 20 до 30 лет, практиков деятельности 2 - 3 раза в неделю. Они были разделены на три группы: лечение иглоукалыванием; плацебо-обман; Управления. Оценивались следующие: болевой порог с алгелометром; максимальная изометрическая мышечная сила; электромиографическая активность; субъективное восприятие боли через визуальную аналоговую шкалу.

После оценок добровольцы были представлены на индукцию ДМИТ, выполняя сгибание и расширение локтя с нагрузкой (бицепсная нить), вплоть до 
максимального предела исполнения движения: 3 серии выполнялись до истощения мышц с интервалом от 4 до 5 минут. После этой процедуры, состояние, в котором мышца была до иглоукалывание была переоценена.

Пункты, выбранные для лечения группы иглоукалывания были: толстый кишечник 4 (рисунок 4A), толстая кишка 11 (рисунок 4В), желудок 36 (рисунок 1В), желчный пузырь 34 (рисунок 11В), которые являются обезболивающими и тонизирующие точки мышц и сухожилий. В группе sham, пункты плацебо были использованы и иглы были введены поверхностно; контрольная группа лиц просто лег. Обе группы оставались в состоянии покоя в течение 20 минут.

Результаты показали: восприятие боли с аналоговой шкалой было уменьшено в группе иглоукалывание; порог боли алгелометром увеличился после вмешательства в этой группе. После вмешательства иглоукалывания, активация мышц бицепса была уменьшена на 30\% при связи с фиктивной и контрольной группой. Мышечная сила, после DMIT, снизилась на 48\% в исследуемой группе, будучи ниже, чем в фриктивных и контрольных группах (58\% и 56\% соответственно). Все группы представили максимальный дефицит изометрической мышечной силы после протокола индукции dmit: иглоукалывание уменьшилось на 26\%; фриктивные 29\%; контролировать 33,5\%.

Тем не менее, был сделан вывод, что иглоукалывание было эффективным в немедленном улучшении восприятия боли и увеличение порога algelomer, обеспечивая нервно-мышечные изменения, но не улучшение сократительной производительности мускулатуры.

В другом исследовании Tolen ${ }^{\text {ti }} \mathrm{n} 74$, он оценил влияние аурикулотерапии на боль, фрункциональность и подвижность людей с хронической болью в пояснице. Разделил 31 участника на три группы: экспериментальные с одноразовыми иглами из нержавеющей крови 1,5 мм; экспериментальный с семенами горчицы; контроль без вмешательства. Визуальная аналоговая шкала была использована для оценки боли; для теста функциональности были использованы вопросник по 
вопросам инвалидности в области поясничного отдела в Квебеке и постоянный тест; была выполнена поясничная подвижность.

Вмешательства проводились в течение 4 недель, будучи еженедельной сессией, применяемой в точках: Шэнмен, Рим, Симпатический, Анальгезия, Мышечная релаксация, Ламбар и надпочечник позвоночника (рисунок 10). После интервала в 1 неделю после последнего применения, лица были переоценены с тем же протоколом.

Результаты показали улучшение состояния боли в пояснице, а также улучшение функциональной способности в обеих экспериментальных группах, в отличие от контроля, что не было существенной разницы по отношению к первоначальной боли. Никакой разницы не было найдено между методами, выполняемыми (иглы и семян), что свидетельствует о том, что оба полезны для облегчения от хронической боли в пояснице и увеличение функциональной способности.

Рисунок 23: Очки уха

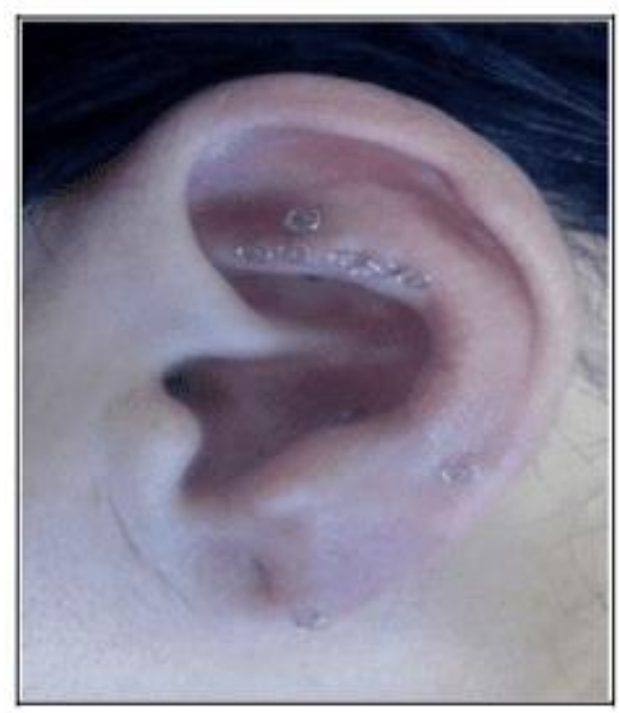

Источник: Tolentino ${ }^{74}$ 


\section{ЗАКЛЮЧИТЕЛЬНЫЕ СООБРАЖЕНИЯ}

На основе литературы, анализируя все результаты и их научные данные, считается, что лечение иглоукалыванием эффективно в лечении, улучшении работоспособности и профилактике травм у профессиональных и любительских спортсменов. Лица, получающие вмешательство, даже если у них есть какой-то тип травмированных осложнений, проблема менее серьезна и быстро восстанавливает органическую функцию, то есть спортсмен, который страдает от некоторых видов травм и выполняет иглоукалывание, эта невзгода будет, как правило, минимальны и раннего возвращения деятельности.

Даже спортсмены, которые не используют иглоукалывание для того, чтобы предотвратить профилактику и представить поражения, вмешательство это представляет клинические доказательства, основанные на нейрофизиологии, опиоидного релиза, с акцентом на лечение боли и улучшение благополучия пациента .

Иглоукалывание вмешательства, хотя это тысячелетняя техника, по-прежнему растет на Западе, выполняет большие результаты в клинической практике, вопросы профилактики травм опорно-одиночного, а также в профилактике и лечении заболеваний психосоциальной, острой и хронической боли.

Благодаря балансу энергетической системы, иглоукалывание не только лечит физическое благополучие, но и психическое благополучие, потому что теоретическая основа техники не отделяет тело от ума, пользующего эмоциональный стресс, снижая беспокойство и балансируя человеческого разума.

\section{ссылки}

1. Ching N. O livro de ouro da medicina chinesa. 3. ed. Rio de Janeiro: Objetiva; 1991.

Disponível em: https://www.nucleodoconhecimento.com.br/здравоохранение/иглоукалывание-в- 
2. Malveira CL, Souza FCS, Rocha TBX. Biomecânica do movimento isométrico de pedala antes e após aplicação de acupuntura: Um estudo preliminar. Motric. 2012 Set;8(52):630-9.

3. Sousa NR. Relação entre a reatividade de pontos de acupuntura e atividade física com afecções ortopédicas determinadas por exames de imagens em equinos. Botucatu. Tese [Doutorado em Biotecnologia Animal] Universidade Estadual Paulista; 2015.

4. Silveira NC, Martins RCC. Eficácia da acupuntura para o tratamento da fibromialgia: Uma revisão sistemática. Psicol e Saúde em Debate. 2018 Fev; 4(1):85-105.

5. Sant' Anna FM, Rangel VM, Mota DDS. Tratamento da Tenossinovite de De Quervain por Acupuntura - Relato de Caso. Vittalle. 2018 Mar; 30(1):130-6.

6. Tsuchiya M, Sato EF, Inoue M, Asada A. Acupuncture enhances generation of nitric oxide and increases local circulation. Anesth Analg. 2007 Feb; 104(2):3017.

7. Tavares MG, Machado AP, Motta BG, Borsatto MC, Rosa AL, Xavier SP. Electro-acupuncture efficacy on pain control after mandibular third molar sugery. Brz Dent J. 2007; 18(2):158-62

8. Hutchinson AJ, Ball S, Andrews JC, Jones GG. The effectiveness of acupuncture in theating chronic non-specific low back pain: a systematic review of the literature. J Otthop Surg Res. 2012 Oct 30;7:36.

9. Moniz PJL. Avaliação da acupuntura no desempenho do rugby. Coimbra. Dissertação [Mestrado Integrado em Medicina] - Faculdade de Medicina da Universidade de Coimbra; 2015.

10. Magalhães PC. Efeito da acupuntura na prevenção da hemorragia pulmonar induzida por exercício em cavalos puro sangue inglês de corrida. Botucatu. Dissertação [Mestrado em Biotecnologia Animal] - Universidade Estadual Paulista; 2016.

11. Matias $B$ et al. Acupuntura de equilíbrio como coadjuvante no tratamento de disfunções temporomandibulares. Ação Odonto. 2018 Jun; 1(1):65-72. 
12. Franco A. Acupuntura Ajuda Atletas nas Lesões e na Performance. Jornal da Madeira 2016 agosto 2;p.25.

13. Lopes SS, Mota MPG. Efeito da acupuntura na resistência física após exercícios repetitivos de tornozelo - Estudo experimental. R bras Ci e Mov. 2018 Jul;26(1):13-21.

14. Lopes SS, Mota MPG. Influência da acupuntura no limiar de percepção dolorosa de musculatura submetida a esforço repetitivo. Br J Pain. 2018 Jul; 1(3):207-11.

15. Cohen M, Abdala RJ, Ejnisman B, Amaro JT. Lesões Ortopédicas no futebol, Rev. Bras. Ortop 1997 Dez;32(12):940-44.

16. Dias Junior JC, Marino DM. Acupuntura na prevenção de lesões musculares em atletas de futebol profissional. Rev Fisioter S Fun. Jan-Jul:6(1):36-42.

17. Wen TS. Acupuntura Clássica Chinesa. 15. ed. São Paulo: Cultrix, 2006.

18. Maciocia G. Os fundamentos da medicina chinesa: um texto abrangente para acupunturistas e fitoterapeutas. São Paulo: Roca; 1996.

19. Ross J. Combinações dos Pontos de Acupuntura: A Chave para o Êxito Clínico. 1 ed. São Paulo: Roca, 2003.

20.Santos VC, Kawano MM, Banja RA. Acupuntura na melhora da performance em atletas juvenis de handebol, Rev Saúde e Pesq 2008 Set-Dez;1(3):331-35.

21. Rubio K, Godoy Moreira F. A dor em corredores com fascite plantar: o uso da acupuntura, Rev Dor 2008 Jul-Set;9(3):1290-1296.

22. Pires TF, Pellegrinotti IL. Acupuntura na Performance Atlética: Estudo

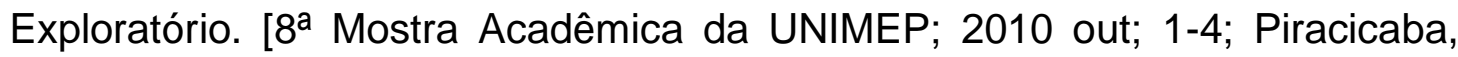
Brasil].

23. Yang HY, Liu TY, Gao M. Electrical acupoint stimulation increases athletes rapid strength, Zhongguo Zhen Jiu 2006 May;26(5): 313-315.

24. Luna MP, Fernandes Filho J. Efeitos da Acupuntura na performance de Atletas velocista de alto rendimento do Rio de Janeiro. Fit e Perform J 2005 Julh/Ago;4(4):199-214.

25. Ehrlich D, Haber P. Influence of acupuncture on pysical performance capacity and Haemodynamic Parameters. J. Sports Med 1992 May;13(6): 486-91.

Disponível em: https://www.nucleodoconhecimento.com.br/здравоохранение/иглоукалывание-в- 
26. França D, Fernandes-Senna V, Cortez CM. Acupuntura cinética como efeito potencializador dos elementos moduladores do movimento no tratamento de lesões desportivas. Fisioter Bras 2004 mar-abr; 5(2):111-8.

27. Wadsworth L T. Acupuncture in sports medicine. Curr Sports Med Rep 2006 Feb; 5(1):1-3.

28. Barela J A. Estratégias de Controle em Movimentos Complexos: Ciclo Percepção - Ação no Controle Postural. Rev Paul de Educ Fís 2000; 3: 79-88.

29. Papler PG et al. Reabilitação do joelho. In: Greve J.M. A. e Amattuzzi, M.M. Medicina de reabilitação aplicada à ortopedia e traumatologia. São Paulo: Roca, 1999.

30. Gemeo LH. Ignatti C. Acupuntura como Ferramenta Auxiliar do Aumento da Performance Desportiva. In: Anais do Simpósio Internacional de Ciências Integradas da UNAERP; 2004 ; Guarujá, Brasil. São Paulo: Universidade de Ribeirão Preto Campus Guarujá; 2004. p. 1-9.

31. Rossetto SC. Acupuntura nos Esportes. 1 ed. São Paulo: Phorte, 2009.

32. Pelham TW, Holt LE, Stalker R. Acupuncture in human Performance. J Strength Cond Res 2001 May;15(2):266-71.

33. Myamoto T. Acupuncture treatment for muscle injury. Japa Journ of Phys Fit and Spor Med 1997; 43(2):39-41.

34. Fry AC, Kraemer KJ. Resistance exercise overtraining and overreaching: neuroendocrine responses. Sports Med 1997 Feb;23(2): 106-29.

35. Frasca L. Desempenho na Ponta da Agulha. Rev Farmac 2011 out-nov:44-5.

36. Costa V. Acupuntura Previne Lesões e ajuda a melhorar o Desempenho nas Pistas [periódico na internet]. 2013 [acesso em 22 jan 2017] Disponível em: http://blogs.oglobo.globo.com/pulso/post/acupuntura-previne-lesoes-ajudamelhorar-desempenho-nas-pistas-500798.html.

37. Luna M. Os Benefícios da Acupuntura no Esporte. 2016 [acesso em 22 jan 2017] Disponível em: http://www.ibramrp.com.br/noticia/49/os-beneficios-daacupuntura-no-esporte. 
38. Akimoto T, Nakahori C, Aizawa K, Kimura F, Fukubayashi T, Kono I. Acupuncture and responses of imunoligic and endocrine markers during competition, Med Sci in Sports Exerc 2003 Ago;35(8):1296-1302.

39. Bopp-Limoge C. L`acupuncture Permet-elle D`ameliorer les Performances Sportives Stude Personnelle a Propos de 35 Sportifs de haut niveau. These Medicine 1998; 117:215.

40. Lin ZP et al. Effects of acupuncture stimulation on recovery ability for male elite basketball athletes. Amer Jour of Chin Med 2009; 37(3):471-81.

41. Lin, ZP et al. Effect of auricular acupuncture on oxygen consumption of boxing athletes. Chin Med Jour 2009; 22(13):1587-90.

42. Dhillon $S$ et al. The acute effect of acupuncture on $20-\mathrm{km}$ cycling performance. Clin Jour of Spo Med 2008; 18(1):76-80.

43. Hubscher $\mathrm{M}$ et al. Immediate effects of acupuncture on strength performance: a ramdomized, controlled crossover trial. Euro Jour of Appli Physi 2010; 110(2):353-58.

44. Geng $\mathrm{L} J$ et al. Investigation on the effects of ear acupressure on exerciseinduced lactic acid levels and the implications for athletic training. Amer Jour of Acupu 1995; 23(4).

45. Fonseca LP, Lessa JFM. Efeito da Aplicação da Acupuntura na Resistência Muscular Localizada de Membros Superiores em Praticantes de Exercício Resistido. Brasília. Monografia [Graduação em Fisioterapia] - Centro Universitário de Brasília; 2011.

46. Belmiro H, Vicentini D, Camilotti CM. Efeitos da Acupuntura no Desempenho Motor de Atletas. Rev Fac Educ Fis 2013 jul-set; 11(3):176-91.

47. Angeli AL, Fernandes JGJ, Luna SPL. Acupuncture Applied Equine Sports Medicine, Ver Acad 2007 Jul-Set;5(3):325-33.

48. Staud R. Mechanisms of acupunture analgesia: effective therapy for musculoskeletal pain? Curr rheumatol Rep. 2007 Dec;9(6):473-81

49. Bucinskaite V, Lundeberg T, Stenfors C, Ekblom A, Dahlin L, Theodorsson E. Effects of electro-acupuncture and pysical exercice on regional concentrations of neuropeptides in rat brain, Brain research 1994 Dec;666(1): 128-32. 
50. Shang C. Prospective tests on biological models of acupuncture. Evid Based Complement Alternat Med. 2009 Mar; 6(1):31-9.

51. Bowsher D. Mechanisms of acupuncture. In: Filshie J, White A. editors. Medial Acupuncture: a western scientific approach. London: Churchill Livingstone; 1988:69-82.

52. Ma SX. Neurobiology of acupuncture: Toward CAM. Evid Based Complement Alternat Med. 2004 Jun;1(1):41-7.

53. Li J, Wang Q, Liang H, Dong H, Li Y, Ng EH, et al. Biophysical characteristics of meridians and acupoints: a systematic review. Evid Based Complement Alternat Med. 2012;2012793841.

54. Cardeal EL, Oliveira KB, Aoki MN, Amarante MK, Oliveira CEC, Suzuki S, et al. Aspectos imunológicos da acupuntura. Biosaúde 2005 Dez:7(1/2):49-60.

55. Szabó MVRS, Bechara GH. Acupuntura: Bases Científicas e Aplicações. Ciência rural 2001:31(6):1091-99

56. Saad M. A Medicina tradicional chinesa tem base científica?. Einstein: Educ Contin Saúde 2008: 6(3):122-6.

57. Alvarenga TF, Amaral CG, Steffen CP. Ação da acupuntura na neurofisiologia da dor: revisão bibliográfica. Rev Amazôn Scienc \& Helth 2014 Out/Dez:2(4):29-36.

58. Pereira FAO. Evidências científicas da ação da acupuntura. Perspectivas 2005 jan/jul:4(7):88-105.

59. Taffarel MO, Freitas PMC. Acupuntura e analgesia: aplicações clínicas e principais acupontos. Ciênc Rural 2009 Dez:39(9): 2665-72.

60. Lopes LF, Lopes MC, Fialho FAP, Gonçalves AL. Sistema de conhecimento para diagnóstico em acupuntura:uma modelagem usando o CommonKADS. Gest Prod 2010 Dez:x(x):1-15.

61.Zhu J, Arsovska B, Kozovska K. Acupuncture treatment for sports injury hamstring muscles group, Inter J Clin Exper Med Sci 2017 Nov;3(6):71-3.

62. Vickers AJ, Cronin AM, Maschino AC, Lewith G, MacPherson H, Foster NE, et al. Acupuncture for chronic pain individual patient data meta-analysis, Arch Intern Med 2012 Oct;172(19):1444-53. 
63. Toda S. Effect of acupuncture on carnitine for skeletal muscle fatigue, Chin Med 2012 Jan;3:9-12.

64. Lopes SS, Mota MPG. Influência da acupuntura no limiar de percepção dolorosa de musculatura submetida a esforço repetitivo, Br J Pain 2018 julset;1(3):207-11.

65. Lee, SH, Chung, SH, Lee, JS, Kim, SS, Shin, HD, Lim, BV, et al. Effects Acupunturaq on the 5-hydroxytryptamine synthesis and tryptophan hydroxylase expression in dorsal in the dorsal raphe of exercice rats. Neurocienses Letters 2002 Oct;332(1): 17-20.

66. Zyloney CE, Jensen K, Polich G, Loiotile RE, Cheetham A, LaViolette PS, et al. Imaging the functional connectivity of the Periaqueductal Gray during genuine and sham electroacupuncture treatment. Mol pain. 2010 Nov;6:80

67. Minori AET, Mejia DPM. Atuação da Acupuntura para o Tratamento de LER/DORT no Ombro. Goiânia. Monografia [Pós Graduação em Acupuntura] Faculdade Ávila; 2007.

68. Brum KN, Alonso, AC, Brech GC. Tratamento de massagem e acupuntura em corredoresrecreacionais com síndrome do piriforme. Arq Cienc Sau 2009 abrjun; 16(2): 62-6.

69. Hongwen S. Clinical Observation on Acupuncture Treatment of Piriformis Syndrome. J Tradit Chin Med. 2003 mar; 23(1):38-9.

70. Rocha TBX, Vilela Junior GB, Martins GC, Manzatto L, Grande AJ. Análise Comparativa Eletromiográfica do Reto Femoral em Isometria na Posição Inferior do Agachamento Wall Slide, antes e após a Aplicação da Acupuntura no Ponto ST45. Rev Bras Cien e Mov 2012 jul; 20(4):92-8.

71. Pinheiro RG, Mejia DPM. Efeito da Acupuntura na Melhora do Paciente com Quadro Álgico de Lesão de Menisco Medial. Goiânia. Monografia [Pós Graduação em Acupuntura] - Faculdade Ávila; 2012.

72. Nunes EA, Mejia DPM. Tratamento de Acupuntura para Combater Dores nos Ombros. Goiânia. Monografia [Pós Graduação em Acupuntura] - Faculdade Ávila; 2012. 
73. Parisotto D. Efeito Imediato da Aplicação da Acupuntura na Dor Muscular Tardia e na Capacidade de Contração Muscular. Curitiba. Dissertação [Mestrado em Fisiologia] - Universidade Federal do Paraná; 2014.

74. Tolentino F. Efeito de um Tratamento comAuriculoterapia na Dor, Funcionalidade e Mobilidade de Adultos com Dor Lombar Crônica. Rio Claro. Dissertação [Mestrado em Desenvolvimento Humano e Tecnologias] Universidade Estadual Paulista - UNESP; 2016.

Представлено: апрель 2019 года.

Утверждено: октябрь 2019 года. 